\title{
Seismic Fragility and Life Cycle Cost Analysis of Reinforced Concrete Structures with a Hybrid Damper
}

\author{
Naga Dheeraj Kumar Reddy Chukka $\mathbb{D}^{1},{ }^{1}$ L. Natrayan $\mathbb{D}^{2},{ }^{2}$ and Wubishet Degife Mammo $\mathbb{D D}^{3}$ \\ ${ }^{1}$ Department of Civil Engineering, Aditya College of Engineering and Technology, Surampalem, India \\ ${ }^{2}$ Department of Mechanical Engineering, Saveetha School of Engineering, SIMATS, Chennai, Tamil Nadu 602105, India \\ ${ }^{3}$ Mechanical Engineering Department, Wollo University, Kombolcha Institute of Technology, Kombolcha, South Wollo - 208, \\ Amhara, Ethiopia \\ Correspondence should be addressed to Naga Dheeraj Kumar Reddy Chukka; dheerukumbi@gmail.com, L. Natrayan; \\ natrayanphd@gmail.com, and Wubishet Degife Mammo; wubishetdegife7@gmail.com
}

Received 2 August 2021; Revised 10 September 2021; Accepted 28 September 2021; Published 8 October 2021

Academic Editor: Daniele Perrone

Copyright (c) 2021 Naga Dheeraj Kumar Reddy Chukka et al. This is an open access article distributed under the Creative Commons Attribution License, which permits unrestricted use, distribution, and reproduction in any medium, provided the original work is properly cited.

\begin{abstract}
The main objective of this research is to develop a hybrid damper by combining the friction damper (FD) and the X-shaped metallic damper (XMD) to enhance the performance of a building under seismic excitations with different peak ground accelerations (PGA). Four- and twelve-storey-reinforced concrete buildings were retrofitted with the hybrid damper, and seismic fragility, nonlinear dynamic, and life cycle cost analyses were executed on both structures to evaluate the performance of the hybrid damper and are compared with the FD and XMD of same yield load. According to the nonlinear dynamic analysis results, when a four-storey structure is installed with the XMD, FD, and hybrid dampers, the percentage of deduction of the average of the maximum interstorey drifts is 63,67 , and 74 , respectively. When a twelve-storey structure is installed with the XMD, FD, and hybrid dampers, the percentage of deduction of the average of the maximum interstorey drifts is 59,64 , and 71 , respectively. So the performance of the hybrid damper is superior to the XMD and FD in reducing interstorey drift of both structures. Results also show that the hybrid damper has enhanced the energy dissipation capacity compared to the XMD and FD under earthquakes with both low and high PGA values. According to fragility analysis results, the performance of the hybrid damper is superior to the $\mathrm{XMD}$ and FD in reducing the probability of attaining the collapse state. Life cycle cost analysis results show that structures with the hybrid damper acquired the shortest repair time and lowest repair cost.
\end{abstract}

\section{Introduction}

Many researchers are working on the earthquake-resistant systems to diminish the losses created by seismic excitations. Earthquake-resistant systems are categorized as passive energy dissipation system, active energy dissipation system, and base isolation. The passive energy dissipation system or dampers are well known when compared to the active energy dissipation system and base isolation due to their low cost. Among the dampers, friction and metallic dampers are widely used. Metallic dampers were used for the first time in the buildings by Skinner et al. [1] to dissipate the earthquake energy. Out of all the metallic dampers, the X-shaped metallic damper is popular and widely used because it is easy to manufacture. In order to improve the mechanical characteristics of this device, many researchers worked on this damper [2-5]. The friction damper was introduced by Pall and Marsh [6] and is popularly known as Pall friction damper. Later, Anagnostides et al. [7] developed the rotational and linear frictional dampers whose hysteresis loops were broad and stable. In order to further improve this device, many researchers worked on this damper [8-11]. But these dampers executed great performance only when subjected to the single source of earthquake excitation, which is either high or low PGA. To improve the energy dissipation capacity and to enhance the performance of a building under earthquake excitations with both high and low PGA, many of the investigators worked on using two 
different devices together instead of one damper. Marko et al. [12] worked on the combination of viscoelastic damper and friction daper. To improve seismic performance of a building under multilevel vibrations, Ibrahim et al. [13] developed a hybrid device by combining the metallic yielding device and the viscoelastic damper. The viscoelastic damper dissipates the input earthquake energy under low levels of vibration. The metallic yielding device and the viscoelastic damper work together and dissipate earthquake energy under high levels of vibration. Karavasilis et al. [14] developed a hybrid device by combining a self-centering device that has friction-based energy dissipation properties and a viscoelastic damper to enhance the steel frames performance under multilevels of earthquake ground motion. Lee et al. [15] proposed a wall-type damping system, which is a combination of a nonuniform steel strip damper and a shear-type friction damper used for strengthening of moment resisting framed structures under multilevels of earthquake ground excitation. From the above-mentioned studies, it can be noticed that hybrid dampers displayed great performance than the individual dampers.

This study focuses on the development of a hybrid damper by combining the FD and the XMD to enhance the seismic performance of a building when subjected to earthquake ground motions with different PGA values. The FD dissipates the energy for earthquake ground motions with low PGA values. The FD and the XMD work together and dissipate the energy for earthquake ground motions with high PGA values. To estimate the performance of the hybrid damper, a four-storey and a twelve-storey-reinforced concrete buildings were retrofitted with the hybrid damper, and the nonlinear dynamic analysis was executed on both structures by using eight earthquake ground excitations and simultaneously the hybrid damper performance is compared with the FD and the XMD of same yield load. Along with the nonlinear dynamic analysis, the seismic fragility analysis and the life cycle cost analysis were also executed on both the structures without dampers and with the FD, XMD, and hybrid dampers.

\section{Hybrid Damper}

The FD and the XMD are parallelly connected to each other in a hybrid damper, as shown in Figure 1(a).

$\mathrm{X}$-shaped yielding plates are placed parallel to one another, and top and bottom of these plates are attached with the top plate and bottom plate, respectively; this complete setup is called the XMD. Two exterior plates are positioned on either side of these X-shaped yielding plates. In between both exterior plates and the top plate, friction pads with the coefficient of friction equal to 0.5 are positioned. Three bolts are used to fix the exterior plates firmly, and these bolts are passed through a hole in the top plate in such a way that bolts and the top plate will not be in contact with each other and at the bottom both the exterior plates and the bottom plate are connected firmly. Recess is made on both sides of the top plate and inside of exterior plates where pads are positioned to stop radial elongation and lateral movement of pads because of clamping force caused by bolts. Friction pads are made up of brake pad material, which shows consistent behaviour over many cycles of loading. Rectangular plates are positioned in between the exterior plates and bolts to uniformly dispense the clamping force. This complete setup is positioned on chevron bracing, and the top of the hybrid damper is attached to the beam as shown in Figure 1(b). As top of the hybrid damper, i.e., the top plate (since the height of the XMD is more than the height of exterior plates) is attached to overlying beam and bottom of the hybrid damper is attached to the chevron bracing, X-plates start to dissipate the input energy due to interstorey drift, and exterior plates remain elastic because their top is not attached to the overlying beam. Due to the movement between the top plate and exterior plates, friction is produced since exterior plates are fixed only to the bottom plate. Basic concept of the hybrid damper is that the friction damper dissipates energy for earthquake ground motions with low PGA values. The FD and the XMD work together and dissipate energy for earthquake ground motions with high PGA values.

\section{Seismic Response of Four-Storey and Twelve- Storey Structures with the Hybrid Damper}

3.1. Description of Four- and Twelve-Storey Structures. To calculate the hybrid damper performance, a four-storey and a twelve-storey existing reinforced concrete residential buildings were considered. Then the hybrid damper developed in this study is installed in both the buildings, and the buildings with the hybrid damper performance are compared with seismic performance of buildings with the FD and the XMD of same yield load. These two buildings are situated in India zone-V (whose MCE is $0.36 \mathrm{~g}$ PGA). These buildings were designed without taking the earthquake loads into account. Both the buildings are symmetrical and are having 3 bays of $5 \mathrm{~m}$ length in both $X$ and $Y$ directions, as shown in Figure 2.

The storey height of both the buildings is $3.5 \mathrm{~m}$. In a fourstorey building, all beams of size $210 \mathrm{~mm} \times 420 \mathrm{~mm}$ and columns of size $350 \mathrm{~mm} \times 350 \mathrm{~mm}$ were taken for simplicity and similarly in a twelve-storey structure all beams of size $300 \mathrm{~mm} \times 500 \mathrm{~mm}$ and columns of size $550 \mathrm{~mm} \times 550 \mathrm{~mm}$ were taken for simplicity. Wall thickness and floor slab thickness of both the buildings are considered as $150 \mathrm{~mm}$. For both the structures, grade of concrete used was M25 whose characteristic compressive strength is $25 \mathrm{MPa}$, Poisson's ratio is 0.2 , Young's modulus is $25000 \mathrm{MPa}$, and unit weight is $25 \mathrm{kN} / \mathrm{m}^{3}$. For longitudinal and confinement reinforcement, Fe 415 and Fe 250 grades of steel are used, respectively. According to IS [16], dead load is considered as $1 \mathrm{kN} / \mathrm{m}^{2}$ on all floors of the structure and on terrace it is taken as $3 \mathrm{kN} / \mathrm{m}^{2}$. Live load is considered as $3 \mathrm{kN} / \mathrm{m}^{2}$ on all floors of structure and on terrace it is taken as $1.5 \mathrm{kN} / \mathrm{m}^{2}$. Both the buildings were primarily designed using the load combination of 1.5 times dead load +1.5 times live load.

3.2. Modeling for Nonlinear Analysis. According to ASCE/ SEI [17], considering the cracked section, the shear and 


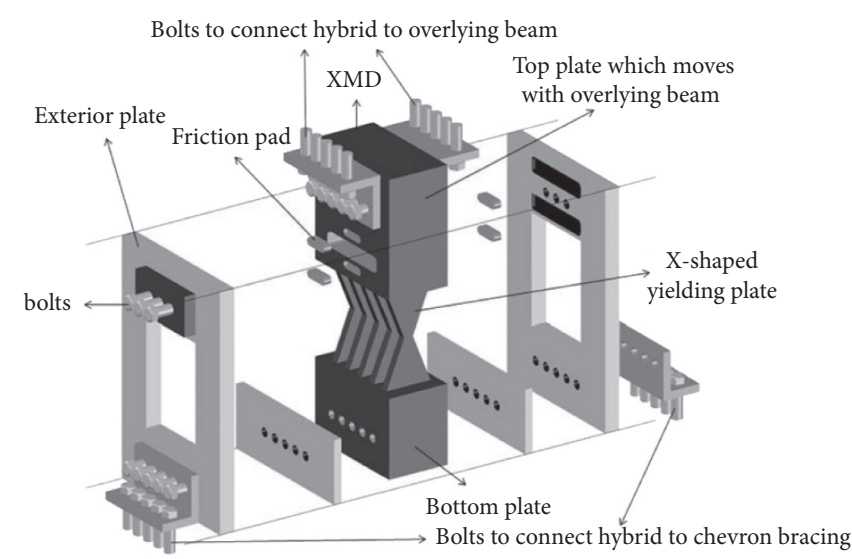

(a)

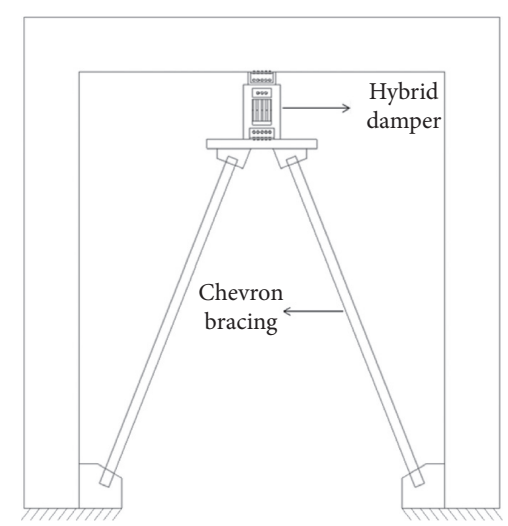

(b)

Figure 1: The hybrid damper. (a) Components of the hybrid damper. (b) Typical installation of the hybrid damper.

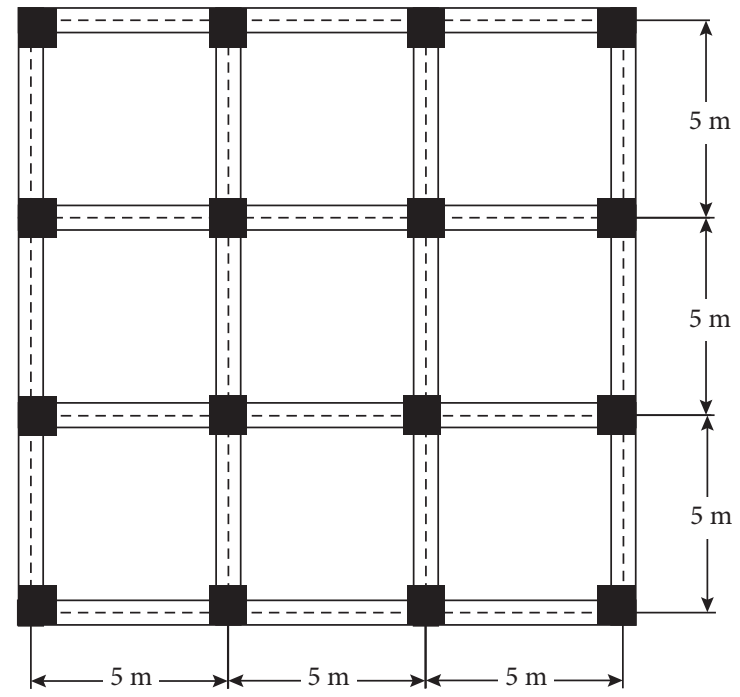

Figure 2: Plan of both four- and twelve-storey buildings.

flexural stiffness of column is decreased to $0.4 E_{c} A_{w}$ and $0.7 E_{c} I_{g}$, respectively; similarly, shear and flexural stiffness of beam is decreased to $0.4 E_{c} A_{w}$ and $0.5 E_{c} I_{g}$, respectively, where $A_{w}$ is the cross-sectional area of web, $E_{c}$ is the modulus of elasticity of concrete, and $I_{g}$ is the moment of inertia of gross section. In order to model the inelastic behaviour of the structures, M3 type of plastic hinges is allotted at ends of beam and P-M2-M3 type of plastic hinges are allotted at ends of column as per the guidelines given in ASCE/SEI [17]. To model the hybrid damper in [18] (2009), plastic (Wen) link element was used. Plastic (Wen) link element was used to model the hysteretic dampers such as the XMD [19] and the FD [20] successfully. Kim and Shin [21] developed a slit-friction hybrid damper and performed experimental analysis on that damper. So the slit-friction hybrid damper is modeled in [18] (2009) by using plastic (Wen) link element and compared with results from the experimental analysis of Kim and Shin [21] to validate the multiphase or hysteresis behaviour of hybrid damper, which is modeled by plastic (Wen) link element and is shown in
Figure 3. According to NourEldin et al. [22] the slit damper in the slit-friction hybrid damper can be modeled by using plastic (Wen) link element.

It can be observed from Figure 3 that force displacement curves of SAP 2000 model are in accordance with force displacement curves from the experimental results of the slit-friction hybrid damper in [21]. So from this it is noted that plastic (Wen) link element can be used to model the hybrid damper in SAP 2000. The installation of dampers in both the four- and twelve-storey structures is shown in Figure 4 .

As shown in Figure 4, the top of dampers is attached to the beam and the bottom of dampers is attached to bracing. For a four-storey structure, ISA $150 \times 150 \times 10$ bracings were used and for a twelve-storey structure ISA $200 \times 200 \times 15$ bracings were used.

3.3. Assessment of Required Damping. Figure 5 shows the interstorey drift of unretrofitted four- and twelve-storey structures when subjected to design earthquake loads (i.e., $1 / 2$ times the MCE) according to IS [23].

But from Figure 5, it is clear that the maximum interstorey drift of both four- and twelve-storey buildings has surpassed allowable storey drift, which is $0.4 \%$ as per the guidelines given in IS [23].

So to retrofit both the four- and twelve-storey structures, first the target displacements (according to ASCE/SEI [17] which is nothing but the roof displacement of the structure under the design earthquake loads) of both structures have to be estimated and then the required damping ratio to satisfy target displacement is calculated with the help of the capacity spectrum method.

As per the guidelines given in ASCE/SEI [17], target displacement $\delta_{t}$ can be evaluated by using

$$
\delta_{t}=C_{0} C_{1} C_{2} S_{a} \frac{T_{e}^{2}}{4 \pi^{2}} g
$$

where $C_{0}$ is the modification factor to relate spectral displacement of an equivalent single degree of freedom system to top floor displacement of the building multiple degree of 


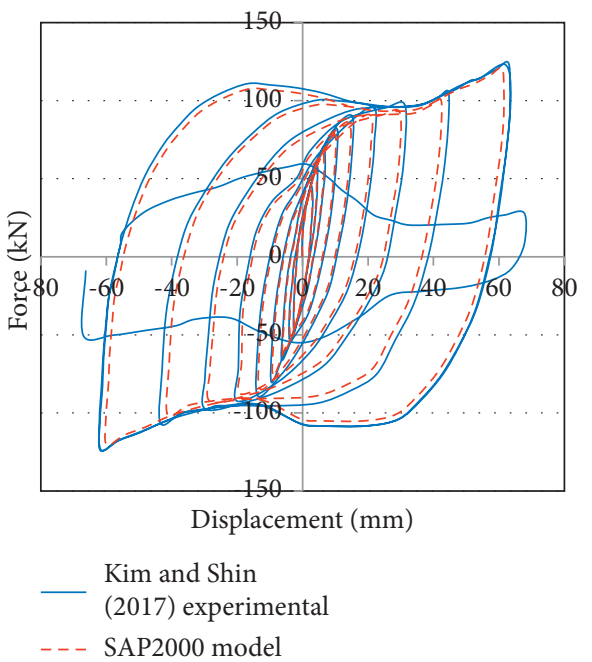

FIGURE 3: Comparison of force displacement loops from the experimental results of the slit-friction hybrid damper in [21] and SAP 2000 model.
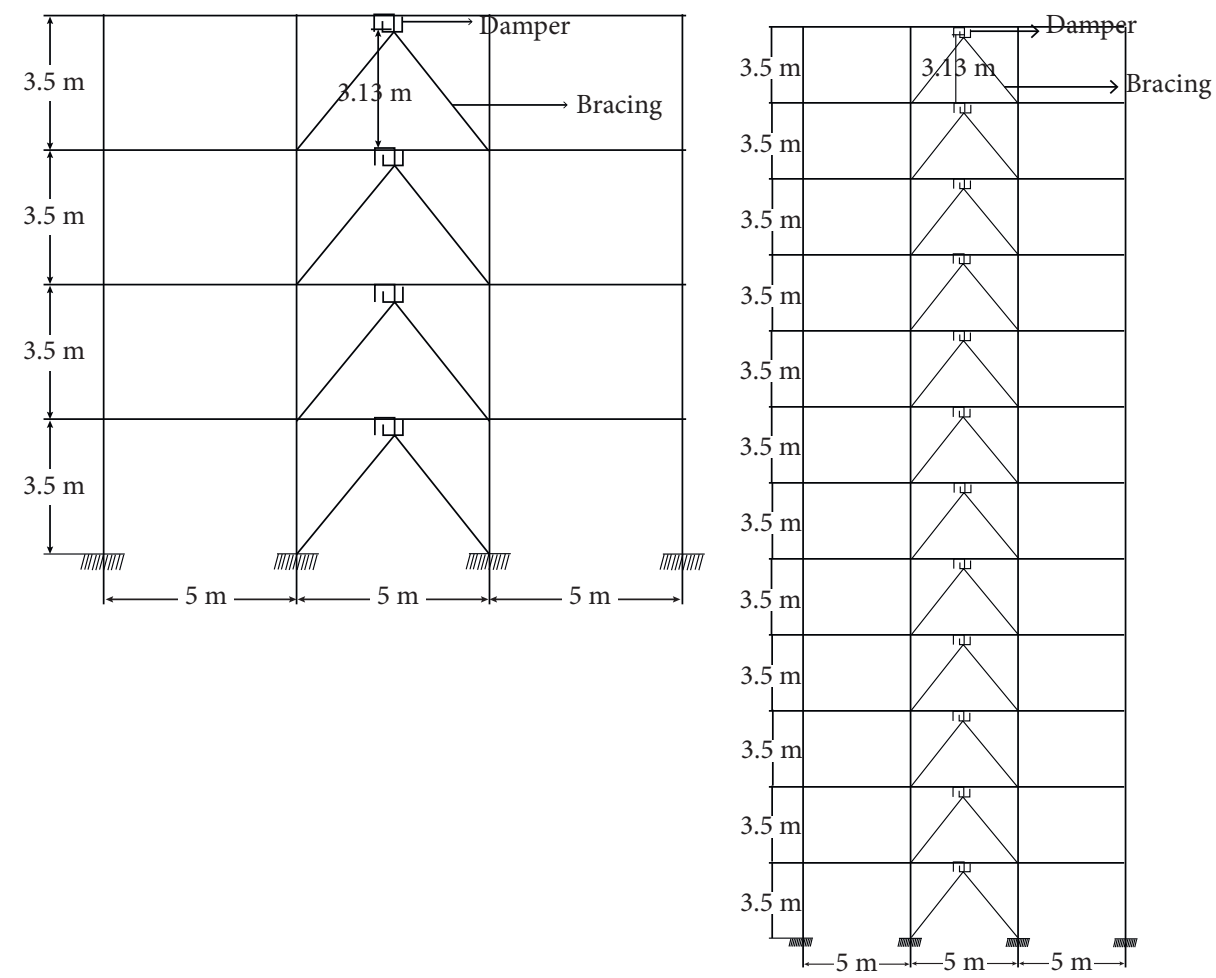

(a)

(b)

FIGURE 4: Installation of dampers in both the structures. (a) Four-storey structure. (b) Twelve-storey structure.

freedom system, which is evaluated as 1.35 and 1.5 for fourand twelve-storey structures, respectively; $C_{1}$ is the modification factor to relate expected maximum inelastic displacements to displacements calculated for linear elastic response, which is evaluated as 0.92 and 1 for four- and twelve-storey structures, respectively; $C_{2}$ is the modification factor to represent the effect of cyclic stiffness degradation, strength deterioration, and pinched hysteresis shape on maximum displacement response, which is evaluated as 0.97 and 1 for four- and twelve-storey structures, respectively; $S_{a}$ is the acceleration of response spectrum, evaluated as 0.5 and 0.21 for four- and twelve-storey structures, respectively; $T_{e}$ is the effective fundamental period of the building, which is 0.542 seconds for four-storey and 1.237 seconds for twelvestorey structures; and $g$ is the acceleration of gravity. By substituting all the values, i.e., $C_{0}, C_{1}, C_{2}, S_{a}$, and $T_{e}$ in (1), target displacement of four- and twelve-storey structures is calculated as $44 \mathrm{~mm}$ and $119.6 \mathrm{~mm}$, respectively. So the 


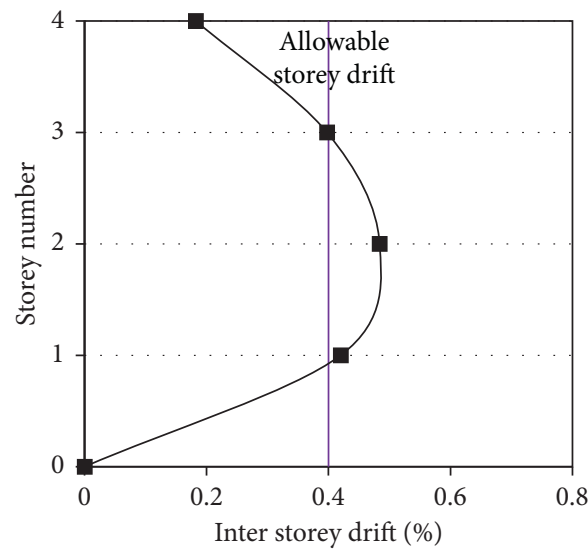

(a)

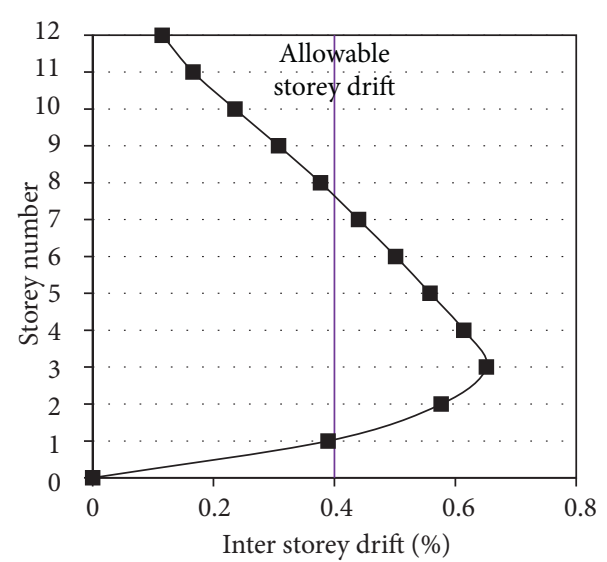

(b)

Figure 5: Interstorey drifts of both the structures under design seismic loads. (a) Four-storey structure. (b) Twelve-storey structure.

maximum interstorey drift of four- and twelve-storey structures corresponding to this target displacements is $0.314 \%$ and $0.28 \%$, respectively.

Once the target displacements are evaluated, then the required damping ratios to satisfy these target displacements are calculated with the help of the capacity spectrum method, which is provided in ATC [24]. According to the capacity spectrum method, the nonlinear static pushover analysis has to be performed for both the structures to obtain the capacity curves, and these curves are converted to $S_{a} S_{d}$ curves or acceleration displacement response spectrum curves. After that demand curves corresponding to $1 / 2$ of MCE have to be constructed, and these curves are converted to curves or acceleration displacement response spectrum curves, as shown in Figure 6.,

Figures 6(a) and 6(b) show the $S_{a} S_{d}$ curves for four- and twelve-storey structures, respectively. The damping ratio required $\left(\beta_{\text {eff }}\right)$ can be attained from the intersection point of demand curve, capacity curve, and spectral displacement equivalent to target displacement. So from Figures 6(a) and 6(b), it can be observed that the damping ratio required for four- and twelve-storey structures is $10 \%$ and $29 \%$, respectively.

Once the damping ratio required is attained, then based on the guidelines given in ASCE/SEI [17], the energy amount to be dissipated by the hybrid damper can be evaluated with the help of the following equations:

$$
\begin{aligned}
& \beta_{\text {eff }}=\beta+\frac{\sum_{j} W_{j}}{4 \pi W_{k}}, \\
& W_{k}=\frac{1}{2} \sum_{i} F_{i} \delta_{i},
\end{aligned}
$$

where $\beta$ is the inherent damping of a building taken as $5 \%$, $W_{j}$ is the sum of energy dissipated by hybrid dampers in the $j t h$ floor, $W_{k}$ is the potential energy of structure, $F_{i}$ is the design earthquake load at the $i$ th storey corresponding to $1 / 2$ of MCE, and $\delta_{i}$ is the displacement of storey.

After finding sum of energy to be dissipated by the hybrid damper, the hybrid damper is designed as follows.
According to Xia and Hanson [3], energy amount dissipated by the XMD is evaluated with the help of

$$
W=\left\{4 \cdot P_{y_{\mathrm{XMD}}} \cdot \Delta_{y_{\mathrm{XMD}}}(\mu-1)\right\} .
$$

According to Constantinou et al. [25], energy amount dissipated by the FD is evaluated with the help of

$$
W=4 \cdot P_{y_{\mathrm{FD}}} \cdot \Delta_{\max _{\mathrm{FD}}} \cdot
$$

In the hybrid damper as the XMD and the $\mathrm{FD}$ are parallelly attached, energy amount dissipated by the hybrid damper is evaluated with the help of

$$
W=\left\{4 \cdot P_{y_{\mathrm{XMD}}} \cdot \Delta_{y_{\mathrm{XMD}}}(\mu-1)\right\}+\left\{4 \cdot P_{y_{\mathrm{FD}}} \cdot \Delta_{\text {max }_{\mathrm{FD}}}\right\},
$$

where $P_{y_{\mathrm{XMD}}}$ is the yield load of the XMD, $\Delta_{y_{\mathrm{XMD}}}$ is the yield displacement of the XMD, $\mu$ is the ductility ratio of the XMD, $P_{y_{\mathrm{FD}}}$ is the yield load of the FD, and $\Delta_{\max _{\mathrm{FD}}}$ is the maximum displacement of the FD. The ductility ratio and yield displacement of the XMD for both the structures are taken as 4.8 and $2.2 \mathrm{~mm}$, respectively [3]. According to Pall and Pall [26], yield force or the slip load of the FD is generally assumed in between $130 \%$ of wind shear force and $75 \%$ of the members yield shear force. Based on this, for four- and twelve-storey structures, yield force of the FD is estimated as $40.4 \mathrm{kN}$ and $123.7 \mathrm{kN}$, respectively. As the maximum interstorey drift for four- and twelve-storey structures is $0.314 \%$ and $0.28 \%$, the maximum displacement of the FD for four- and twelve-storey structures are $10.99 \mathrm{~mm}$ and $9.8 \mathrm{~mm}$, respectively.

By substituting the calculated $\Delta_{y_{\mathrm{XMD}}}, \mu, P_{y_{\mathrm{FD}}}$, and $\Delta_{\max _{\mathrm{FD}}}$ values of four-storey structure and amount of energy to be dissipated by the hybrid damper of a four-storey building, which is estimated by using (2) and (3). Using (6), the $P_{y_{\mathrm{XMD}}}$ of a four-storey building is estimated as $62.2 \mathrm{kN}$. Since the $\mathrm{XMD}$ and the FD are parallelly connected to each other, the yield force of the hybrid damper is estimated as $102.6 \mathrm{kN}$ $(62.2 \mathrm{kN}+40.4 \mathrm{kN})$. When the force on the hybrid damper surpasses $40.4 \mathrm{kN}$, only the FD dissipates the earthquake energy and when force surpasses $102.6 \mathrm{kN}$, which is the yield load of the hybrid damper, the FD, and the XMD works together and dissipates the earthquake energy. 


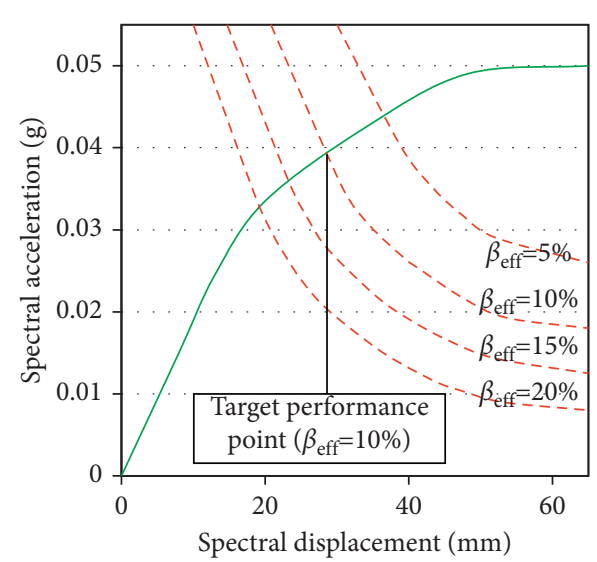

(a)

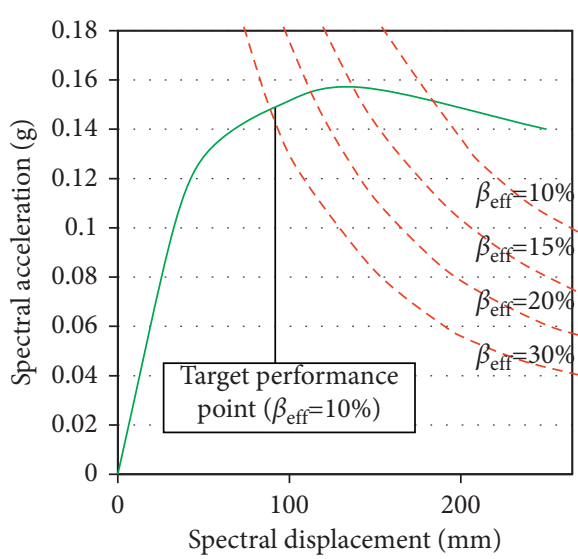

(b)

Figure 6: Assessment of damping ratio required to satisfy target displacement of both the structures. (a) Four-storey structure. (b) Twelvestorey structure.

A similar procedure is used to calculate the yield load of the XMD and the hybrid dampers for a twelve-storey building. The yield load of the XMD is estimated as $189.5 \mathrm{kN}$ and yield load of the hybrid damper is estimated as $313.2 \mathrm{kN}$ $(189.5 \mathrm{kN}+123.7 \mathrm{kN})$ for the twelve-storey structure. The $\mathrm{XMD}$ and the FD of same yield strength of the hybrid damper were used in this analysis for comparison. The natural periods of four- and twelve-storey structures without the dampers are 0.542 seconds and 1.237 seconds, respectively. The natural periods of the four-storey structure with the the $\mathrm{XMD}, \mathrm{FD}$, and hybrid dampers are same and are 0.404 seconds. The natural periods of the twelve-storey structure with the XMD, FD, and hybrid dampers are same and are 0.922 seconds.

In order to estimate the performance of the hybrid damper, all the three dampers, i.e., the FD, XMD, and hybrid dampers, were installed in both four- and twelve-storey structures and then the nonlinear dynamic analysis was executed on both the structures to compare seismic performance of the structure without dampers and structures with the FD, XMD, and hybrid dampers by using [18] (2009) software. Eight different earthquakes having different PGA were chosen, and the average PGA of all these earthquakes is $0.18 \mathrm{~g}$ corresponding to half of the maximum considered earthquake. These earthquakes were provided by PEER NGA database [27], and WAVEGEN software by Mukherjee and Gupta [28] was used to scale and match these eight earthquakes to the target spectrum (i.e., half of MCE). Earthquake ground motion records used for the nonlinear analysis are shown in Table 1.

Both the unscaled and scaled accelerograms of ground motions used for the nonlinear analysis along with their average spectrum and target spectrum are shown in Figure 7.

\section{Results of Nonlinear Dynamic Analysis}

As previously stated, the nonlinear time history analysis was executed on both the structures without and with all the three different dampers under eight earthquakes and the results are as follows.
4.1. Interstorey Drift. Maximum interstorey drifts of a fourstorey structure without the damper in every floor under eight earthquake ground motions and average of these eight interstorey drifts is shown in Figure 8(a). From Figure 8(a), it can be observed that maximum interstorey drifts have exceeded the allowable storey drift of $0.4 \%$ (IS) [23]. But when a four-storey structure is retrofitted with dampers, maximum interstorey drifts are minimised and are within the target drift of $0.314 \%$, as shown in Figure 8(b). Figure 8(b) shows only the average of the maximum interstorey drifts of structure with and without three dampers.

Before retrofitting, the average of the maximum interstorey drift of the four-storey structure under eight earthquake ground motions is $0.483 \%$ (Figure $8(\mathrm{a})$ ), which can be observed in second storey. But when the four-storey building is installed with the $\mathrm{FD}, \mathrm{XMD}$, and hybrid dampers, the average of maximum interstorey drift is $0.159 \%, 0.176 \%$, and $0.124 \%$ (Figure $8(\mathrm{~b})$ ), which implies a reduction of $67 \%, 63 \%$, and $74 \%$, respectively. Maximum interstorey drifts of a twelve-storey building without dampers in every floor under eight earthquake ground motions and their average is shown in Figure 9(a).

Similar to the four-storey building, after installation of dampers, maximum interstorey drifts in a twelve-storey building are minimised and are within the target drift of $0.28 \%$ (Figure 9(b)). Before retrofitting, the average of the maximum interstorey drifts of the twelve-storey structure under eight earthquake ground motions is $0.651 \%$ (Figure 9(a)), which can be observed in the third storey. But when the twelve-storey building is installed with the FD, $\mathrm{XMD}$, and hybrid dampers, the average of maximum interstorey drift is $0.236 \%, 0.264 \%$, and $0.19 \%$ (Figure $9(\mathrm{~b})$ ), which implies a reduction of $64 \%, 59 \%$, and $71 \%$, respectively. So from this it can be noticed that the hybrid damper is performing better than the FD and the XMD in minimising interstorey drift.

4.2. Energy Dissipation. Figure 10 shows the energy dissipation of a four-storey structure without damper and with the hybrid damper when subjected to earthquake 8 . Due to the 
TABLE 1: Ground motions used for the nonlinear analysis.

\begin{tabular}{|c|c|c|c|c|c|}
\hline Sl. no & Earthquake & Station & Year & Magnitude & PGA, $g$ \\
\hline 1 & Imperial Valley-02 & El Centro Array \# 9 & 1940 & 6.9 & 0.06 \\
\hline 2 & Northern Calif-01 & Ferndale City Hall & 1941 & 6.4 & 0.09 \\
\hline 3 & Borrego & El Centro Array \# 9 & 1942 & 6.5 & 0.11 \\
\hline 4 & Southern Calif & San Luis Obispo & 1952 & 6 & 0.13 \\
\hline 5 & Northern Calif-03 & Ferndale City Hall & 1954 & 6.5 & 0.17 \\
\hline 6 & Borrego Mtn & LA-Hollywood Stor FF & 1968 & 6.6 & 0.22 \\
\hline 7 & Borrego Mtn & LB-Terminal Island & 1968 & 6.6 & 0.3 \\
\hline 8 & San fernando & Anza Post Office & 1971 & 6.6 & 0.39 \\
\hline
\end{tabular}

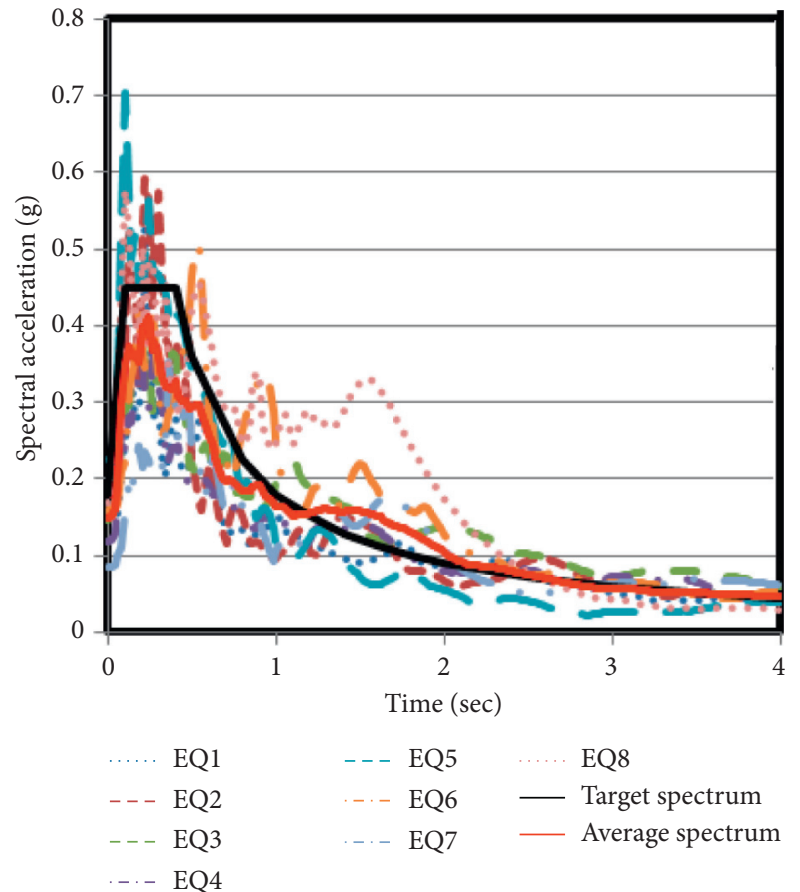

(a)

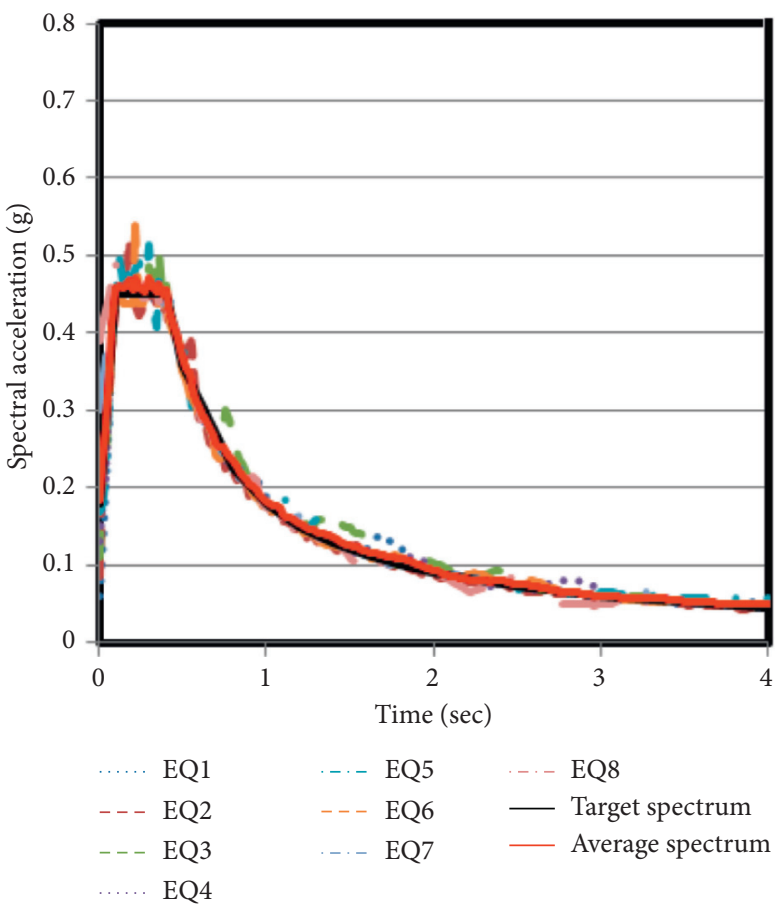

(b)

Figure 7: Accelerograms of ground motions used for the nonlinear analysis. (a) Unscaled. (b) Scaled.

implementation of hybrid dampers into the structure, there will be a change in the amount of the earthquake energy entering the structure when compared to the structure without dampers. When the four-storey structure without dampers is subjected to earthquake 8 , the total amount of input energy entering into the system is $1204.14 \mathrm{kN}-\mathrm{m}$, and when the four storey structure with the hybrid damper is subjected to earthquake 8 , the total amount of input energy entering into the system is $674.19 \mathrm{kN}-\mathrm{m}$. So in order to show comparison between these two structures, these values are converted into percentages and are shown in Figure 10.

Before retrofit of the four-storey structure, $79.8 \%$ of seismic input energy is dissipated by beams and columns and $20.2 \%$ of seismic input energy is dissipated by elastic vibration energy and inherent viscous damping under the earthquake 8, as shown in Figure 10(a). But after the fourstorey building is installed with hybrid damper, seismic energy dissipated by beams and columns is reduced from $79.8 \%$ to $10.12 \%$, which can be seen in Figure 10(b), and it can be noticed that input seismic energy dissipated by the hybrid damper is $74.8 \%$ (i.e., $84.9 \%-10.12 \%$ ). Percentage of energy dissipated by the FD, XMD, and hybrid dampers for both the structures under eight earthquake ground motions is shown in Figure 11.

It can be noticed from Figure 11 that the hybrid damper is dissipating more amount of seismic energy when compared to the FD and the XMD under all eight earthquake ground motions in both four- and twelve-storey structures. From Figure 11(a), it can be observed that for the four-storey structure under earthquake with PGA equal to $0.07 \mathrm{~g}$ (i.e., earthquake 1), the amount of seismic energy dissipated by the $\mathrm{FD}, \mathrm{XMD}$, and hybrid dampers is $22 \%, 15 \%$, and $40 \%$, respectively, and under earthquake with PGA equal to $0.4 \mathrm{~g}$ (i.e., earthquake 8), the amount of seismic energy dissipated by the FD, XMD, and hybrid dampers is $46 \%, 43 \%$, and $75 \%$, respectively. Similarly, from Figure 11(b), it can be observed that for the twelve-storey structure under earthquake with PGA equal to $0.07 \mathrm{~g}$ (i.e., earthquake 1), the amount of seismic energy dissipated by the FD, XMD, and hybrid damperss is $19 \%, 15 \%$, and $37 \%$, respectively, and under 


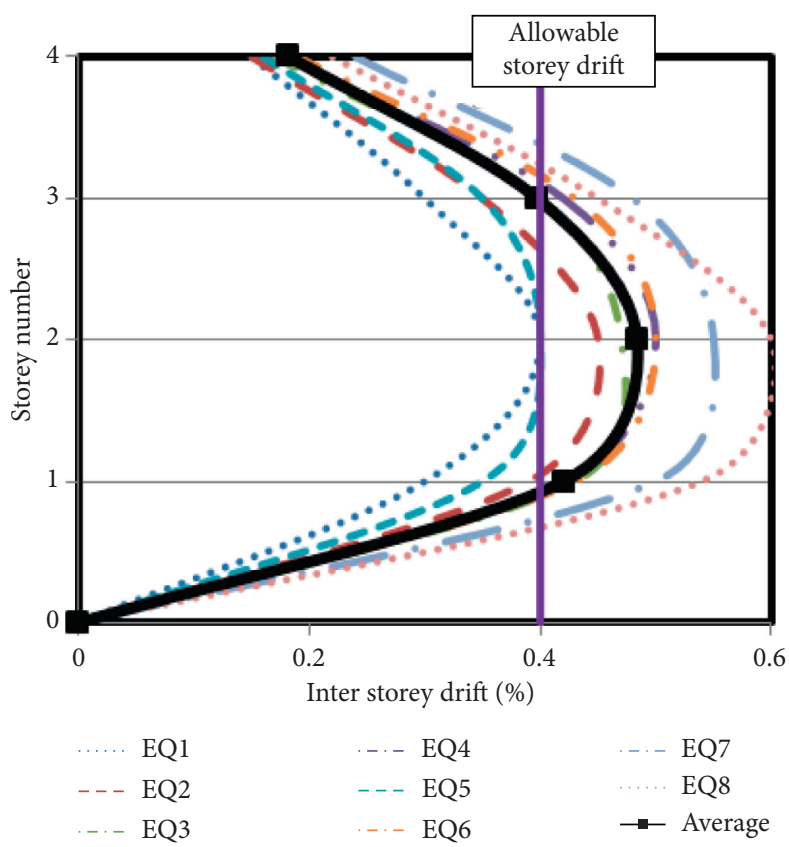

(a)

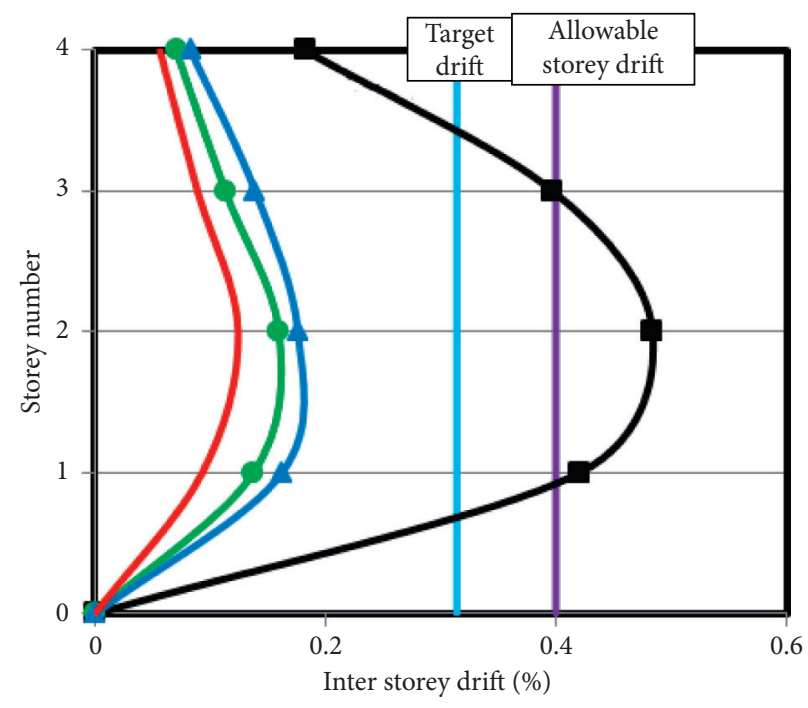

$\rightarrow$ Average without damper $\rightarrow$ Average with FD

$\simeq$ Average with XMD

- Average with hybrid

(b)

FIGURE 8: Interstorey drifts of a four-storey building. (a) Without damper. (b) Average with and without dampers.

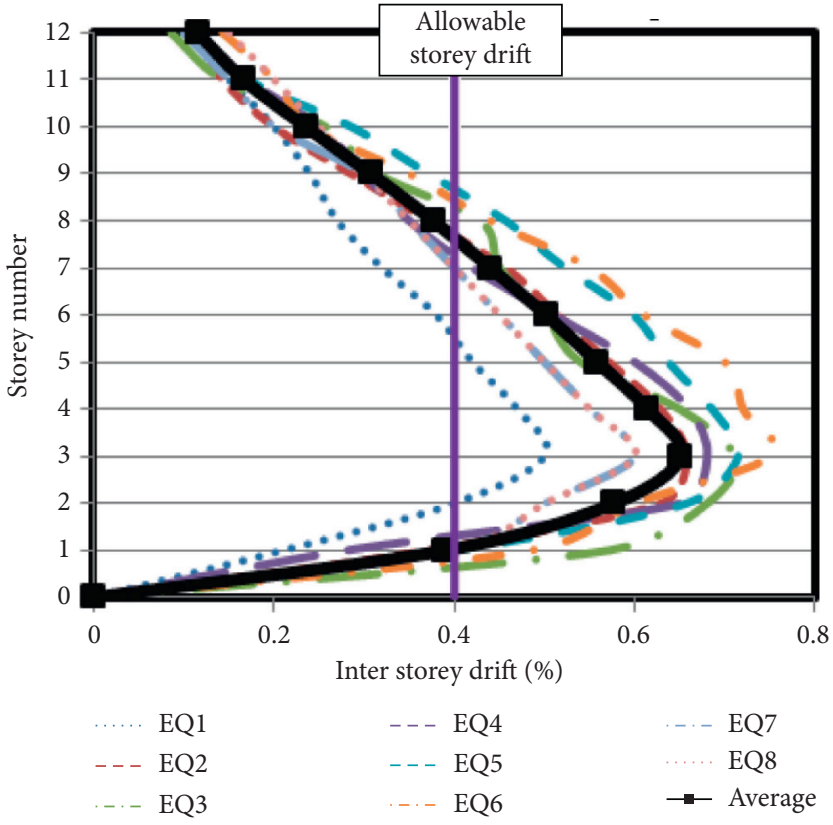

(a)

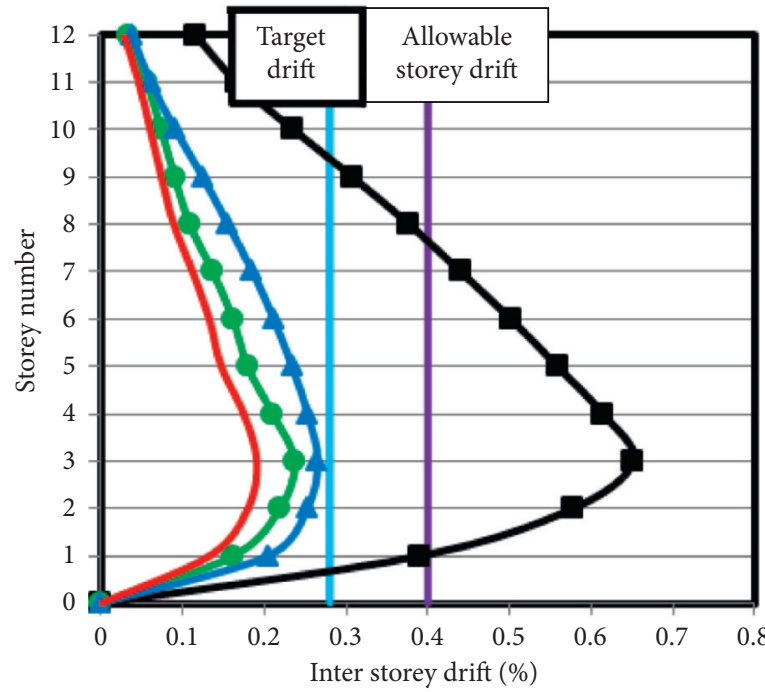

$\rightarrow$ Average without damper $\rightarrow$ Average with XMD

$\rightarrow$ Average with FD

(b)

FIGURE 9: Interstorey drifts of a twelve-storey building. (a) Without damper. (b) Average with and without dampers.

earthquake with PGA equal to $0.4 \mathrm{~g}$ (i.e., earthquake 8), the amount of seismic energy dissipated by the FD, XMD, and hybrid dampers is $45 \%, 43 \%$, and $72 \%$, respectively. From this, it can be noticed that the hybrid damper dissipated more amount of seismic energy than the FD and the XMD under earthquakes with both low and high PGA values.

\section{Seismic Fragility Analysis}

In order to estimate the probability of the structure to reach the complete damage state, i.e., collapse, the seismic fragility analysis is used. Fragility curve can be estimated by using the following eqaution [29]: 


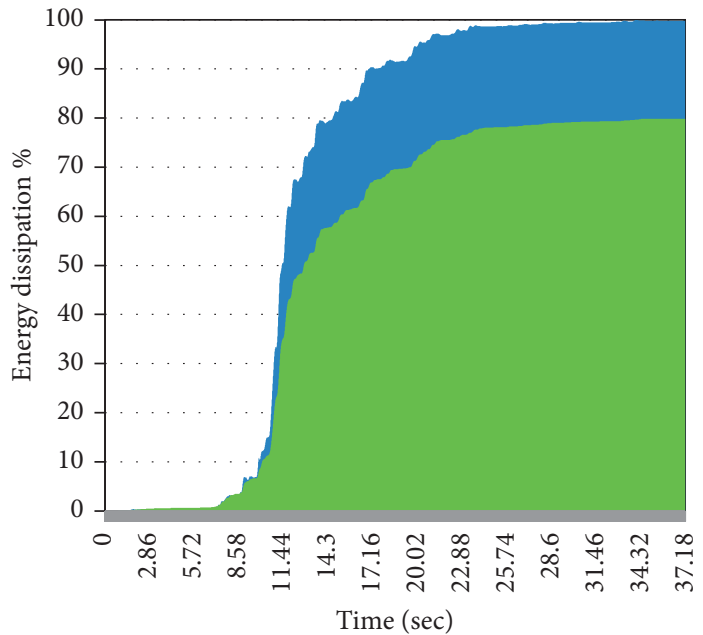

Inherent viscous

- damping + elastic

vibration energy

- Beams and columns

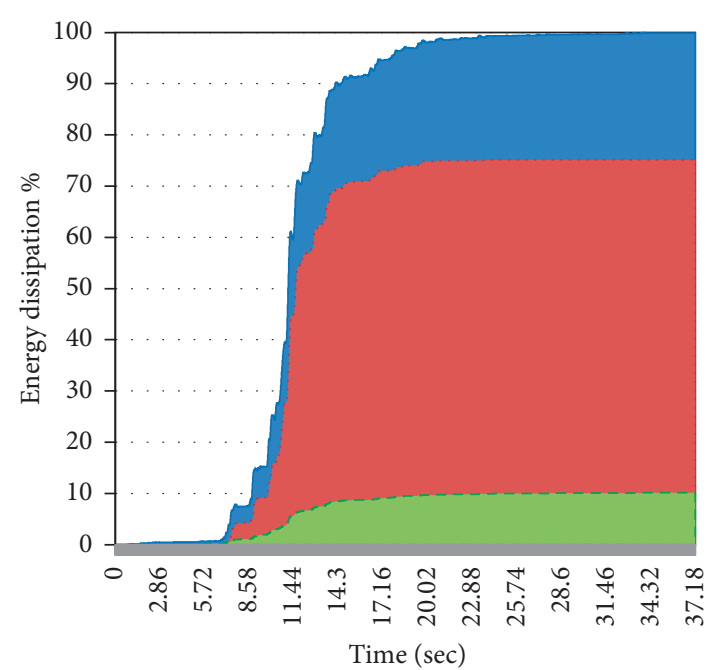

Inherent viscous

- damping + elastic

vibration energy

- Hybrid

5 Beams and columns

(a)

(b)

FIGURE 10: Energy dissipation time histories of a four-storey structure under earthquake 8. (a) Without damper. (b) With hybrid damper.

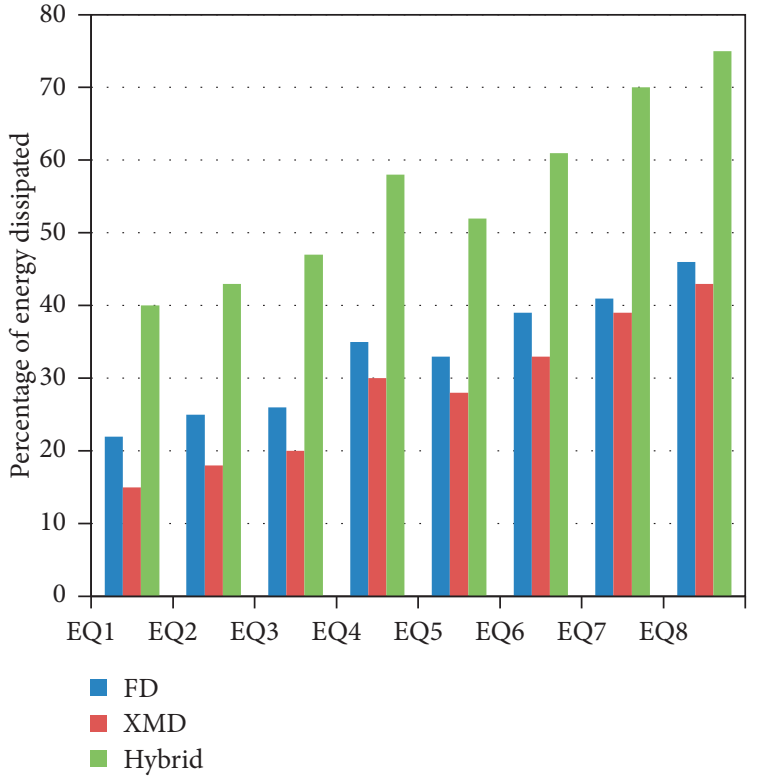

(a)

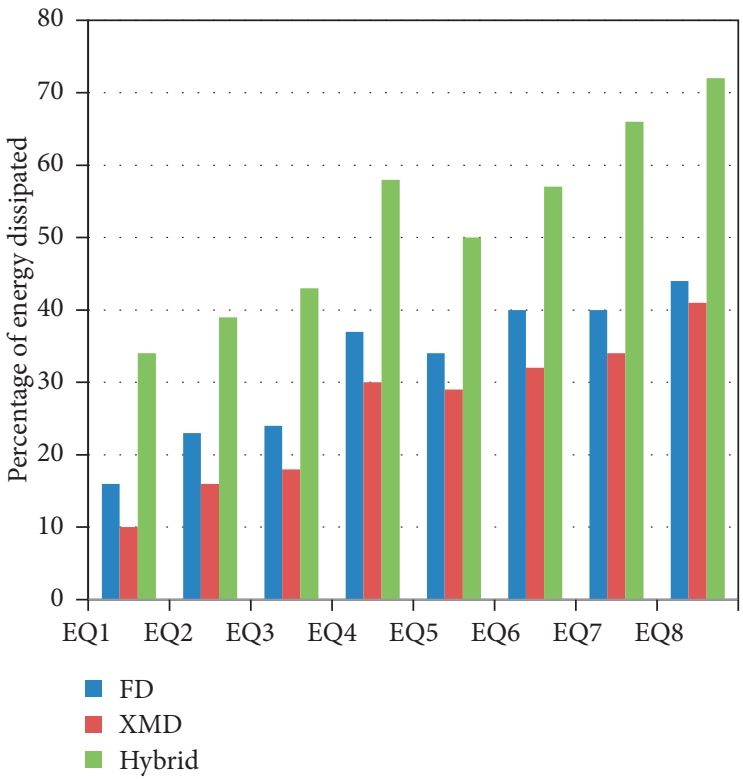

(b)

FIgURE 11: Percentage of energy dissipated by the FD, XMD, and hybrid dampers for both the structures under eight earthquake ground motions. (a) Four-storey structure. (b) Twelve-storey structure.

$$
P(C \mid I M=x)=\Phi\left(\frac{\ln (x / \theta)}{\beta}\right) .
$$

In order to attain the seismic fragility of the model structure, the incremental dynamic analysis (IDA) is to be performed. In this study, IDA is performed using 21 pairs of earthquakes, which are provided by PEER NGA database
(2006). IDA curves of a four-storey building without and with dampers are shown in Figure 12.

From Figure 12(a), it can be noticed that 50\% collapse probability spectral acceleration (which is shown with red line) for structure without damper is $1.9 \mathrm{~g}$. When the FD is installed into the structure, this level has increased from $1.9 \mathrm{~g}$ to $4.9 \mathrm{~g}$, which is shown in Figure 12(b) and similarly when 


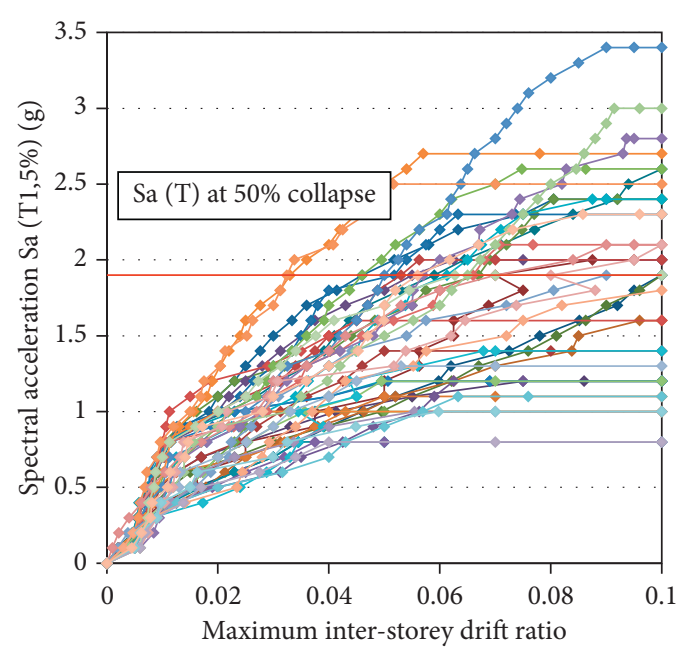

(a)

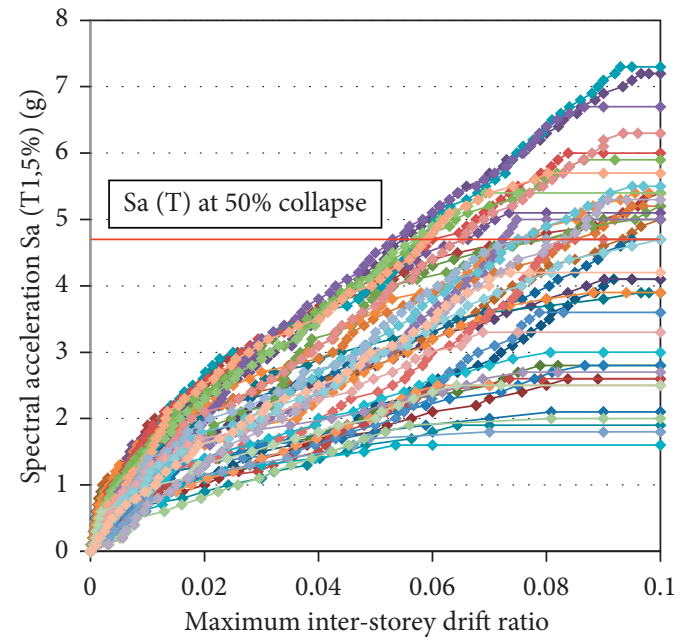

(c)

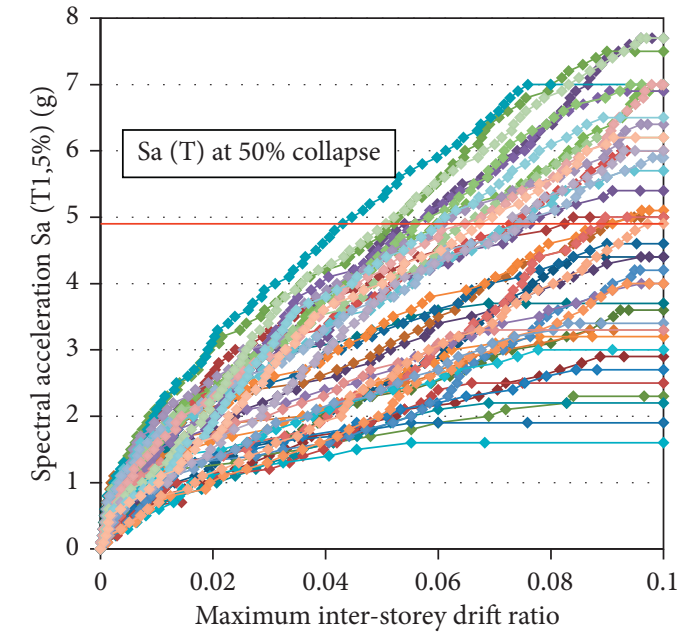

(b)

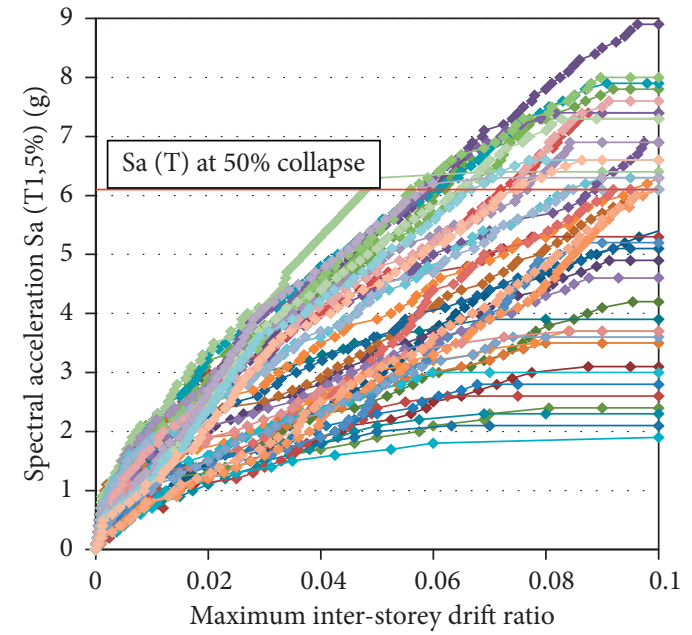

(d)

FIgURE 12: IDA curves of a four-storey building without and with dampers. (a) Without damper. (b) With the FD. (c) With the XMD. (d) With the hybrid damper.

the XMD and the hybrid dampers are installed into the structure, the $50 \%$ collapse probability spectral acceleration is increased from $1.9 \mathrm{~g}$ to $4.7 \mathrm{~g}$ and from $1.9 \mathrm{~g}$ to $6.1 \mathrm{~g}$, respectively, which can be observed from Figures $12 \mathrm{c}$ and $12(d)$. From this, it is clear that the hybrid damper performance is better than the FD and the XMD. IDA curves of a twelve-storey building without and with dampers are shown in Figure 13.

Similar to the four-storey structure, the hybrid damper performance is better than the FD and the XMD even in the twelve-storey structure. It can also be observed that the $50 \%$ collapse probability spectral acceleration for the four- and twelve-storey buildings is $1.9 \mathrm{~g}$ and $0.7 \mathrm{~g}$, respectively (which is shown in Figure 13(a)). So in tall structures, as the number of storeys increases, P-delta effect also increases, which leads the structure to collapse at low level spectral acceleration when compared to the short structures. Fragility curves of a building without and with dampers for both four- and twelve-storey structures are shown in Figure 14.

From Figure 14(a), it can be noticed that at any point of spectral acceleration say $2 \mathrm{~g}$, the probability of collapse of a building without damper, with the FD, XMD, and hybrid dampers is 0.5 (i.e., $50 \%$ ), 0.03 (i.e., $3 \%$ ), 0.04 (i.e., $4 \%$ ), and 0.01 (i.e., 1\%), respectively. From this, it can be observed that the probability of reaching the complete damage states, i.e., collapse, can be reduced by the installation of dampers. Structure with the hybrid damper has attained lowest probability of collapse when compared with structure with the FD and the XMD. Similar trend can be seen in the twelve-storey structure, which is shown in Figure 14(b). From this fragility analysis, it can be observed that the hybrid damper shows superior performance compared to the FD and the XMD in minimising the probability of reaching complete damage states, i.e., collapse. 


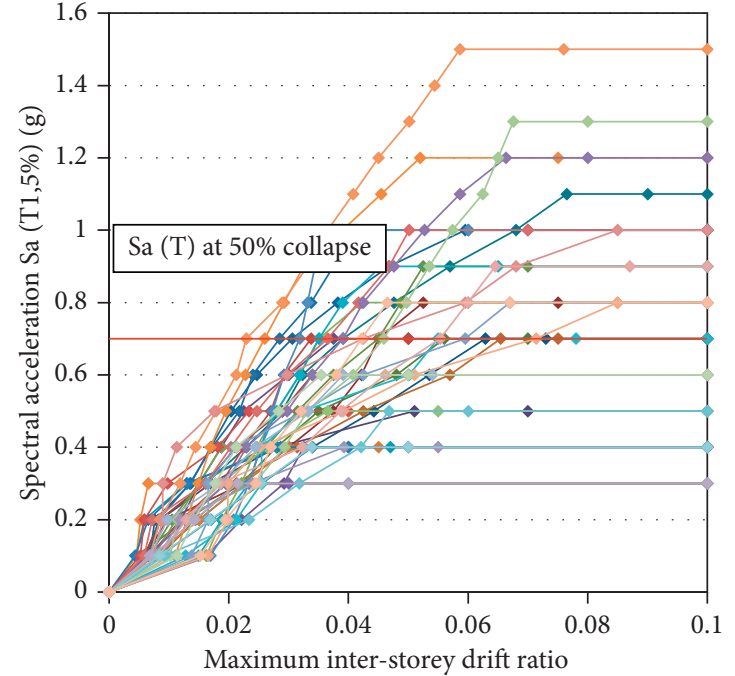

(a)

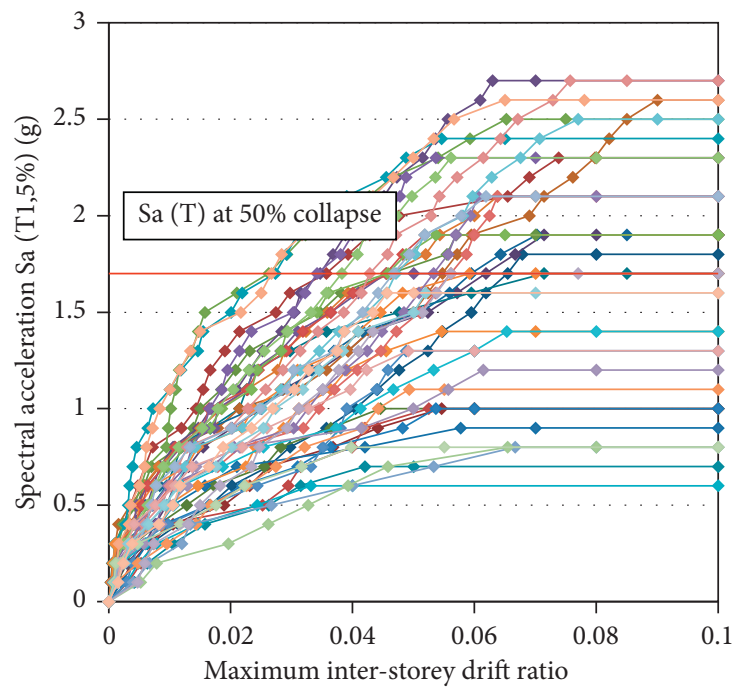

(c)

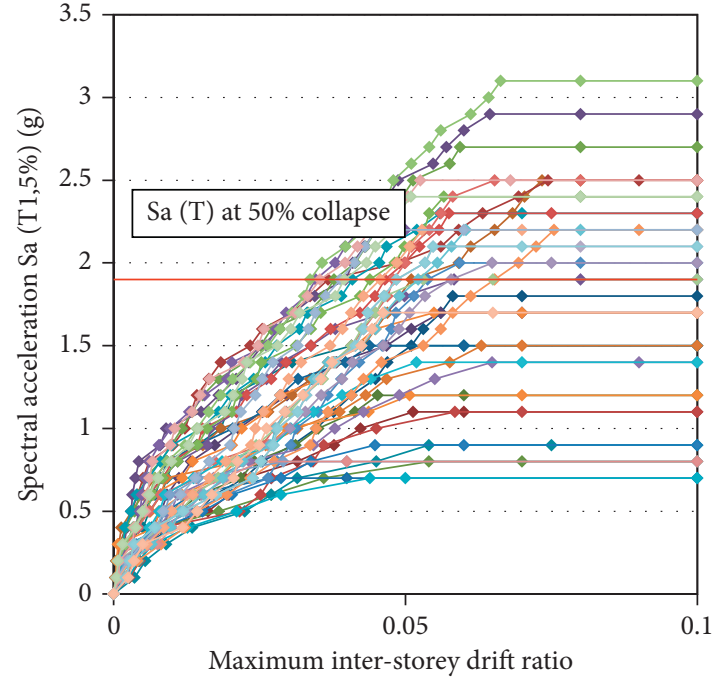

(b)

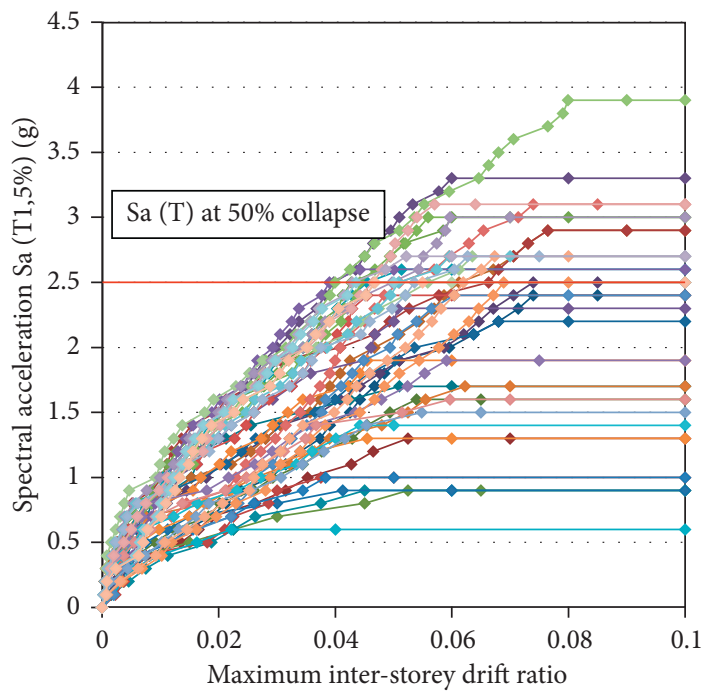

(d)

FIGURE 13: IDA curves of a twelve-storey building without and with dampers. (a) Without damper. (b) With the FD. (c) With the XMD. (d) With the hybrid damper.

\section{Life Cycle Cost Estimation of Four- and Twelve-Storey Structures}

To estimate the life cycle cost of buildings, the FEMA [30] method is used. This method calculates the structure performance in terms of repair time and repair cost. Computer software called Performance Assessment Calculation Tool (PACT) is used in this method to calculate the structure performance in terms of repair time and repair cost. In this method, first, the structure performance model has to be assembled, and the different earthquake intensities have to be defined. Then based on the response of the structure to these different earthquake intensities and by the use of collapse fragility curve, the probability of the damage of structure for different earthquake intensities is estimated.

In this method, repair cost and repair time are governed by damage states of structure. In this research, damage of the hybrid damper is divided into 3 states, i.e., damage state 1 (DS-1), damage state 2 (DS-2), and damage state 3 (DS-3), and similarly damage of the XMD and the FD is divided into 2 states, i.e., DS-1 and DS-2. For the hybrid damper, the repair cost and repair time for DS-1 are determined as the cost and time required for the replacement of friction pads, respectively. Repair cost and repair time for DS-2 are determined as the cost and time required for replacement of the hybrid damper excluding the chevron bracings. The repair cost and repair time for DS-3 are determined as the cost and time required for complete replacement of the hybrid damper including chevron bracings and anchor bolts required to fix the hybrid damper to structural members. For the XMD and the FD, the repair cost and repair time for DS1 are determined as the unit cost and time required for placement of the XMD and the FD, respectively. For the $\mathrm{XMD}$ and the FD, the repair cost and repair time for DS-2 


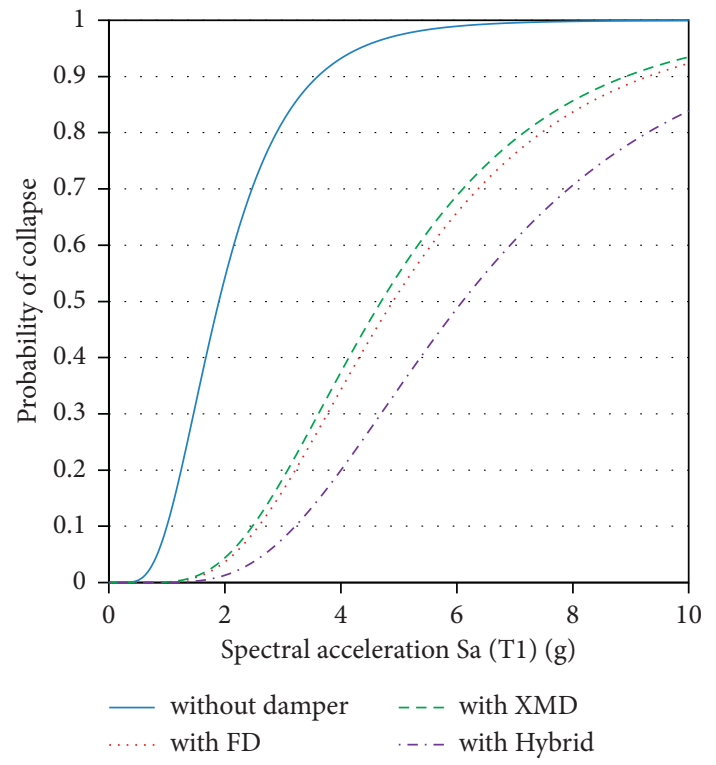

(a)

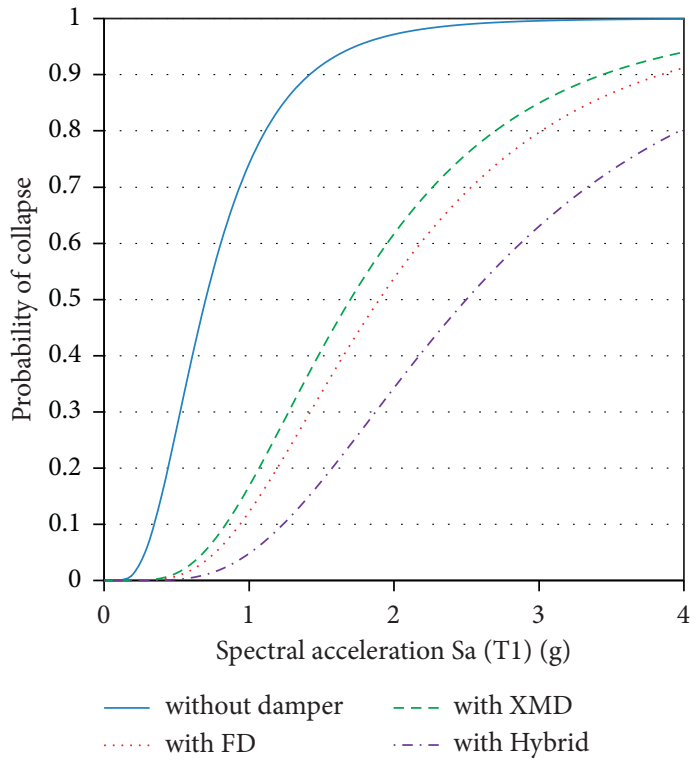

(b)

FIgURE 14: Fragility curves of the four- and twelve-storey buildings without and with dampers. (a) Four-storey structure. (b) Twelve-storey structure.

are determined as the cost and time required for complete replacement of the XMD and the FD including chevron bracings and anchor bolts required to fix the XMD and the FD to structural members, respectively. Tables 2 and 3 show the repair cost and repair time of different damage states for different dampers for both four- and twelve-storey structures, respectively.

Monte Carlo simulation is used in the FEMA [30] method to predict the seismic performance of structure. In this study, the minimum number of realizations used is 500 based on the recommendations provided in FEMA [30]. Three different earthquake intensities having annual probability of exceedance of $20 \%, 10 \%$, and $2 \%$ in 50 years have been used to compare life cycle cost and repair time of both structures without dampers and structures with the $\mathrm{FD}, \mathrm{XMD}$, and hybrid dampers. Based on the international construction market survey [31], the total construction cost or the total replacement cost of four and twelve-storey structures is calculated and is shown in Tables 4 and 5, respectively.

International construction market survey (2019) says the cost of a residential building in India per square meter is 394 $\mathrm{USD}$, and with the exchange rate of $1 \mathrm{USD}=72 \mathrm{INR}$, the total replacement cost of four- and twelve-storey structures is calculated. From Table 2, the cost of the FD, XMD, and hybrid dampers including the chevron bracings for the fourstorey structure is $36,000 \mathrm{INR}, 43,200 \mathrm{INR}$, and 54,000 INR, respectively, and from Table 3, the cost of the FD, XMD, and hybrid dampers including the chevron bracings for the twelve-storey structure is $1,08,000$ INR, $1,29,600$ INR, and $1,62,000$ INR, respectively. Based on these data and since four dampers are used for each floor, the total replacement cost of the structure with the FD, with $\mathrm{XMD}$, and with hybrid damper for both the structures is calculated and is shown in Tables 4 and 5, respectively.
The time required for the construction of four- and twelvestorey structures is assumed to be 100 days and 300 days, respectively, and the time required for the construction of fourand twelve-storey structures retrofitted with dampers is assumed to be 120 days and 350 days, respectively. The total loss threshold is kept as 1 . Since both the structures are residential buildings, in PACT population model type is taken as "Multiunit Residential". Nonlinear time history analyses are performed by using 10 earthquake ground motions on both structures without and with dampers. These earthquakes are scaled to design spectra of three different earthquake intensities, which have annual probability of exceedance of $20 \%$, $10 \%$, and $2 \%$ in 50 years. The analysis results such as maximum interstorey drift ratio and accelerations at each storey are given as input to the PACT software. Then, PACT software uses maximum interstorey drift ratio and structure repair fragility to decide the damage state. If the damage state of a building is irreparable, then the repair cost and repair time of structure are considered as replacement cost and replacement time, respectively. Cumulative distribution of repair cost and repair time of four-storey structure without and with dampers under three different intensity earthquakes calculated using PACT is shown in Figures 15 and 16, respectively.

Figure 15 is plotted between the probability of nonexceedance and the repair cost of the structure without and with dampers under three intensity earthquakes. From Figure 15, it can be observed that the probability of nonexceedance for a given repair cost of structure without damper is smaller (i.e., probability of exceedance is larger) than the building with the XMD, FD, and hybrid dampers under all the three intensity earthquakes. From Figure 15(a) i.e., for intensity 1 earthquakes, at any given repair cost say 25,00,000 INR, the probability of nonexceedance of the building without damper and with the 
TABLE 2: Repair cost and repair time of different damage states for the FD, XMD, and hybrid dampers for the four-storey structure.

\begin{tabular}{|c|c|c|c|c|c|c|}
\hline & \multicolumn{2}{|c|}{ DS-1 } & \multicolumn{2}{|c|}{ DS-2 } & \multicolumn{2}{|c|}{ DS-3 } \\
\hline & Repair cost (INR) & Repair time (days) & Repair cost (INR) & Repair time (days) & Repair cost (INR) & Repair time (days) \\
\hline FD & 21,600 & 3 & 36,000 & 7 & - & - \\
\hline $\mathrm{XMD}$ & 28,800 & 3 & 43,200 & 7 & - & - \\
\hline Hybrid damper & 10,800 & 3 & 39,600 & 5 & 54,000 & 10 \\
\hline
\end{tabular}

TABle 3: Repair cost and repair time of different damage states for the FD, XMD, and hybrid dampers for the twelve-storey structure.

DS-1 DS-2 DS-3

Repair cost (INR) Repair time (days) Repair cost (INR) Repair time (days) Repair cost (INR) Repair time (days)

\begin{tabular}{lllllll}
\hline FD & 64,800 & 3 & $1,08,000$ & 7 & - & - \\
XMD & 86,400 & 3 & $1,29,600$ & 7 & - & - \\
Hybrid damper & 32,400 & 3 & $1,18,800$ & 5 & $1,62,000$ & 10 \\
\hline
\end{tabular}

TABLE 4: Replacement cost of the four-storey structure without and with dampers.

\begin{tabular}{|c|c|c|c|c|}
\hline & $\begin{array}{l}\text { Structure without } \\
\text { dampers }\end{array}$ & Structure with the FD & $\begin{array}{c}\text { Structure with the } \\
\text { XMD }\end{array}$ & $\begin{array}{l}\text { Structure with the hybrid } \\
\text { damper }\end{array}$ \\
\hline Total replacement cost (INR) & $2,55,31,200$ & $2,61,07,200$ & $2,62,22,400$ & $2,63,95,200$ \\
\hline Core and shell replacement cost (INR) & $1,02,12,480$ & $1,04,42,880$ & $1,04,88,960$ & $1,05,58,080$ \\
\hline
\end{tabular}

TABLE 5: Replacement cost of the twelve-storey structure without and with dampers.

\begin{tabular}{|c|c|c|c|c|}
\hline & $\begin{array}{l}\text { Structure without } \\
\text { dampers }\end{array}$ & Structure with the FD & $\begin{array}{c}\text { Structure with the } \\
\text { XMD }\end{array}$ & $\begin{array}{l}\text { Structure with the hybrid } \\
\text { damper }\end{array}$ \\
\hline Total replacement cost (INR) & $7,65,93,600$ & $8,17,77,600$ & $8,28,14,400$ & $8,43,69,600$ \\
\hline Core and shell replacement cost (INR) & $3,06,37,440$ & $3,27,11,040$ & $3,31,25,760$ & $3,37,47,840$ \\
\hline
\end{tabular}

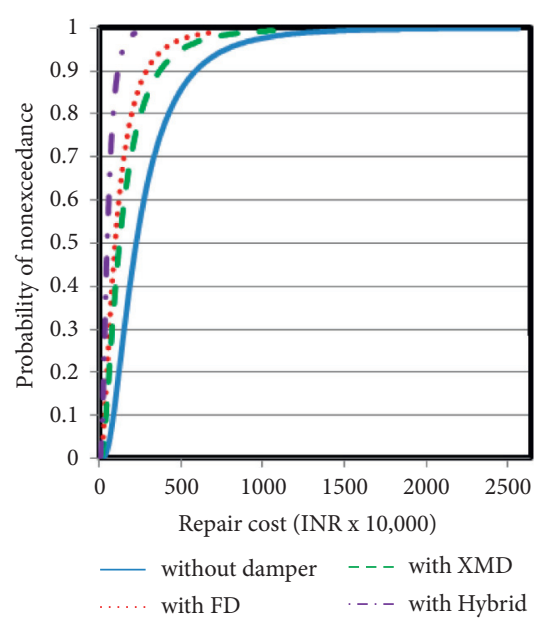

(a)

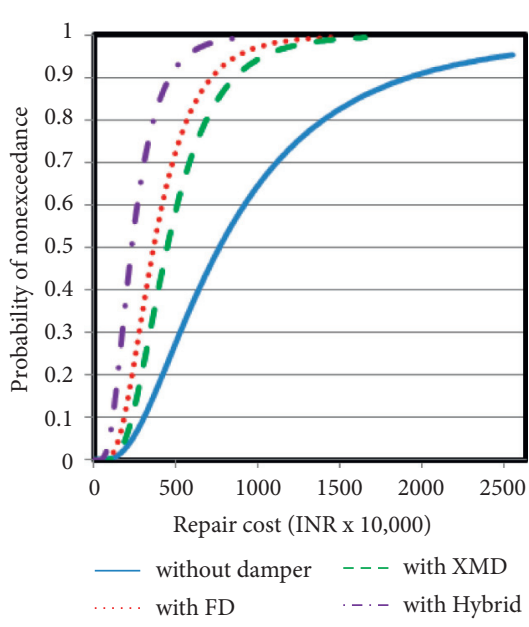

(b)

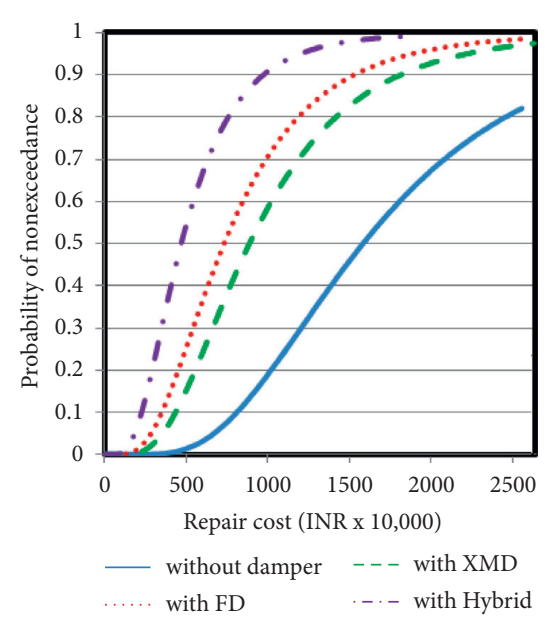

(c)

FIgURE 15: Cumulative distribution of repair cost of a four-storey structure under three different intensity earthquakes. (a) Intensity 1. (b) Intensity 2. (c) Intensity 3.

FD, XMD, and hybrid dampers is $0.55,0.86,0.79$, and 1 , respectively, and similar pattern could be noticed for intensity 2 and 3 earthquakes. From Figure 15, it can also be observed that as intensity increases, damage in a building without damper increases and therefore the probability of nonexceedance decreases. It can also be observed that as intensity increases, difference between the probabilities of nonexceedance of structure without and with dampers also increases. Similar trend can be observed in Figure 16, which shows the cumulative distribution of repair time of the four-storey structure without and with dampers under three intensity earthquakes. 


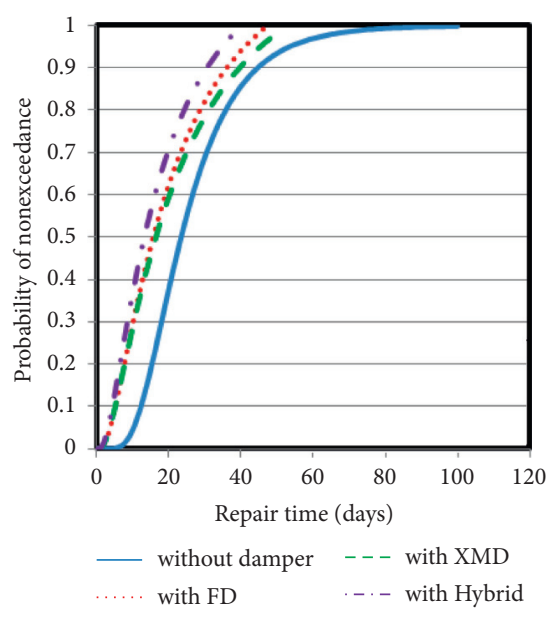

(a)

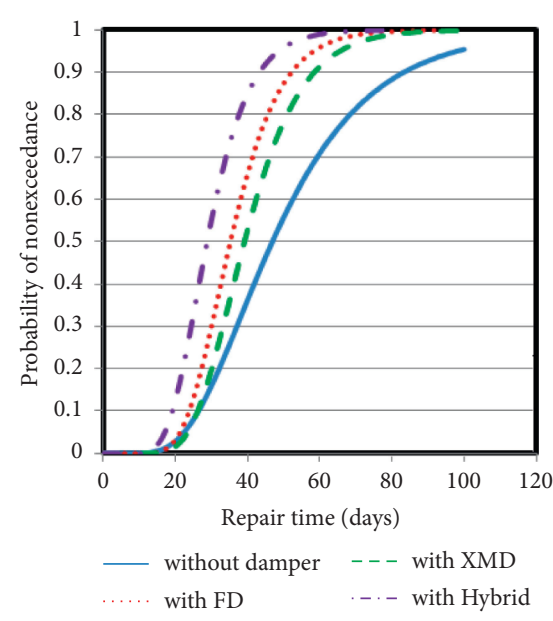

(b)

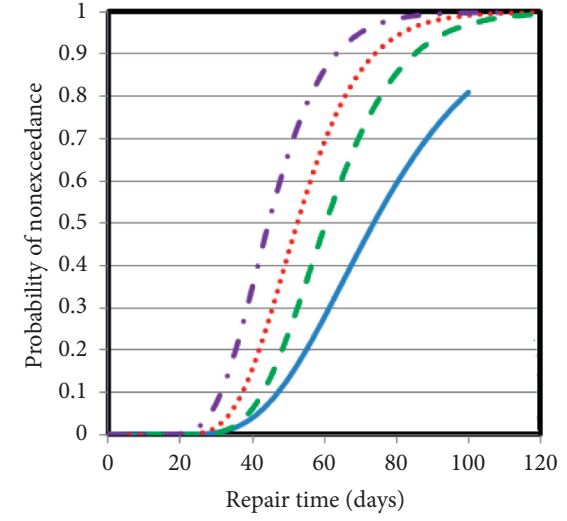

- without damper $\quad---$ with XMD

(c)

FIGURE 16: Cumulative distribution of repair time of a four-storey structure under three different intensity earthquakes. (a) Intensity 1. (b) Intensity 2. (c) Intensity 3.

Table 6 shows mean repair cost of the four-storey structure without and with dampers under three intensity earthquakes that is obtained from Figure 15.

From Table 6, it is clear that the mean repair cost of the structure without damper under intensity 1 earthquakes is $22,78,296$ INR, which is nothing but $8.9 \%$ of total replacement cost (which is also presented in Table 6). When the FD, XMD, and hybrid dampers are installed in the structure, the mean repair cost/total replacement cost is reduced from $8.9 \%$ to $3.7 \%, 4.7 \%$, and $1.8 \%$, respectively. Even though the unit cost of the hybrid damper is greater than the FD and the $\mathrm{XMD}$, the mean repair cost of the structure with the hybrid damper is lower than the structure with the FD and structure with the XMD. Similarly, under intensity 2 and 3 earthquakes, the mean repair cost of a building with the hybrid damper is lower than the structure with the FD and structure with the XMD.

The mean repair time of the four-storey structure without and with dampers under three intensity earthquakes, which is obtained from Figure 16, is shown in Table 7.

From Table 7 , it can be observed that for intensity 1 earthquakes, the mean repair time of the structure without damper is 23 days, which is nothing but $23 \%$ of total replacement time. When the FD, XMD, and hybrid dampers are installed in the structure, the mean repair time/total replacement time is reduced from $23 \%$ to $12.5 \%, 13.3 \%$, and $10.8 \%$, respectively. Even though the time for installation of the hybrid damper is higher than the FD and the XMD, the mean repair time of structure with the hybrid damper is lower than the structure with the FD and structure with the XMD. Similarly under intensity 2 and 3 earthquakes, the mean repair time of structure with the hybrid damper is lower than the structure with the FD and structure with the XMD.

Cumulative distribution of repair cost and repair time of the twelve-storey structure without damper and with the FD, $\mathrm{XMD}$, and hybrid dampers under three different intensity earthquakes calculated using PACT is shown in Figures 17 and 18 , respectively.
TABLE 6: Mean repair cost of the four-storey structure without and with dampers.

\begin{tabular}{|c|c|c|c|}
\hline & \multicolumn{3}{|c|}{$\begin{array}{l}\text { Mean repair cost in INR (mean repair cost/ } \\
\text { total replacement cost }(\%) \text { ) }\end{array}$} \\
\hline & Intensity 1 & Intensity 2 & Intensity 3 \\
\hline $\begin{array}{l}\text { Structure without } \\
\text { damper }\end{array}$ & $\begin{array}{c}22,78,296 \\
(8.9 \%)\end{array}$ & $\begin{array}{c}76,50,000 \\
(29.9 \%)\end{array}$ & $\begin{array}{c}1,57,86,000 \\
(61.8 \%)\end{array}$ \\
\hline $\begin{array}{l}\text { Structure with the } \\
\text { FD }\end{array}$ & $\begin{array}{c}9,72,000 \\
(3.7 \%)\end{array}$ & $\begin{array}{c}36,59,976 \\
(14 \%)\end{array}$ & $\begin{array}{c}73,08,000 \\
(27.9 \%)\end{array}$ \\
\hline $\begin{array}{l}\text { Structure with the } \\
\text { XMD }\end{array}$ & $\begin{array}{c}12,43,944 \\
(4.7 \%)\end{array}$ & $\begin{array}{l}44,55,000 \\
(16.9 \%)\end{array}$ & $\begin{array}{l}89,10,000 \\
(33.9 \%)\end{array}$ \\
\hline $\begin{array}{l}\text { Structure with the } \\
\text { hybrid damper }\end{array}$ & $\begin{array}{c}4,89,600 \\
(1.8 \%)\end{array}$ & $\begin{array}{c}23,04,000 \\
(8.7 \%)\end{array}$ & $\begin{array}{c}47,34,000 \\
(17.9 \%)\end{array}$ \\
\hline
\end{tabular}

Similar to the four-storey structure, the probability of nonexceedance of the twelve-storey building without dampers is smaller (i.e., probability of exceedance is larger) than the structure with XMD, FD, and hybrid dampers under all the three intensity earthquakes. Same as the fourstorey structure, this pattern can be observed in both the cumulative distribution of repair cost and repair time. Mean repair cost and mean repair time of the twelve-storey structure without and with dampers under three intensities are shown in Tables 8 and 9, respectively.

Similar to the four-storey structure, even though the unit cost of the hybrid damper is greater than the FD and the $\mathrm{XMD}$, the mean repair cost of structure with the hybrid damper is lower than the structure with FD and structure with the XMD under all the three intensity earthquakes. Even though the time for installation of the hybrid damper is higher than the FD and the XMD, the mean repair time of structure with the hybrid damper is lower than the structure with the FD and structure with the XMD under all the three intensity earthquakes. So from the life cycle cost analysis of both the structures, it can be stated that the hybrid damper has performed better than the FD and the XMD of same yield strength. 
TABle 7: Mean repair time of the four-storey structure without and with dampers.

\begin{tabular}{lccc}
\hline & \multicolumn{2}{c}{ Mean repair time in days (mean repair time/total replacement time (\%)) } \\
& Intensity 1 & Intensity 2 & $47(47 \%)$ \\
Structure without damper & $23(23 \%)$ & $35(29.1 \%)$ & $73(73 \%)$ \\
Structure with the FD & $15(12.5 \%)$ & $39(32.5 \%)$ & $52(43.3 \%)$ \\
Structure with the XMD & $16(13.3 \%)$ & $29(24.1 \%)$ & $60(50 \%)$ \\
Structure with the hybrid damper & $13(10.8 \%)$ & $44(36.6 \%)$ \\
\hline
\end{tabular}

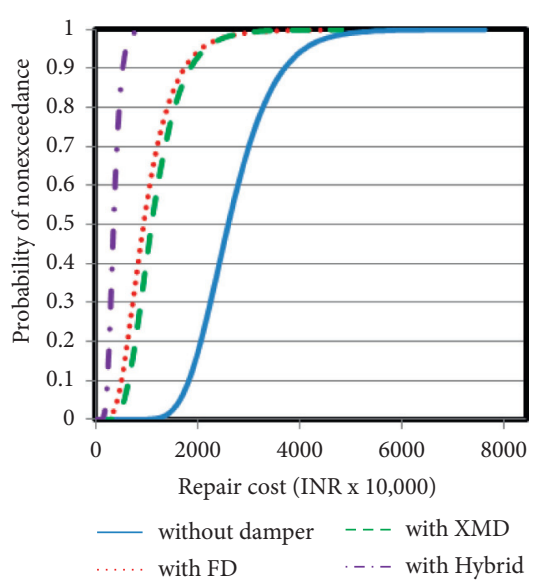

(a)

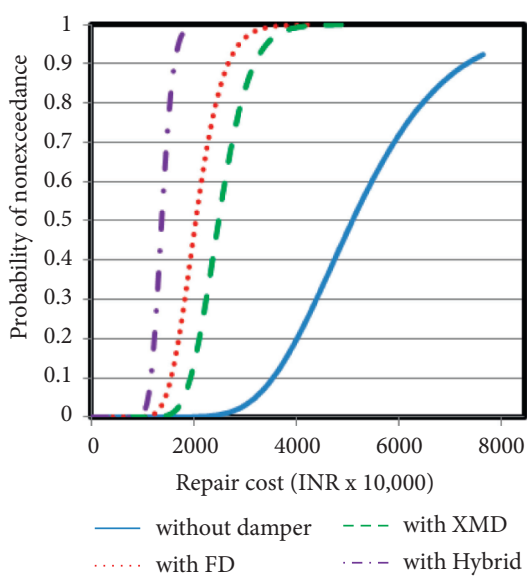

(b)

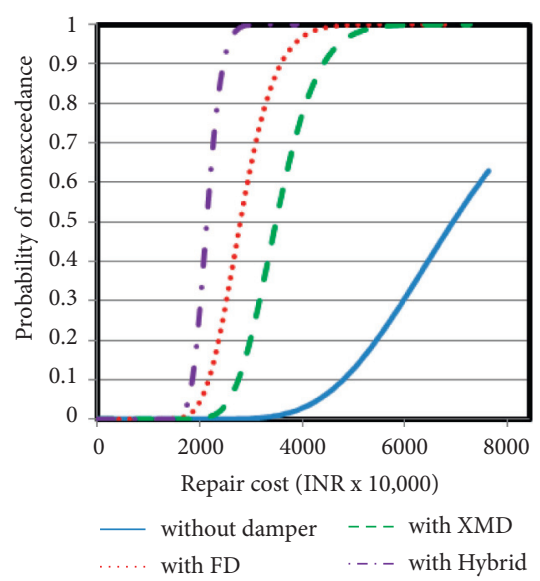

(c)

Figure 17: Cumulative distribution of repair cost of a twelve-storey structure under three different intensity earthquakes. (a) Intensity 1. (b) Intensity 2. (c) Intensity 3.

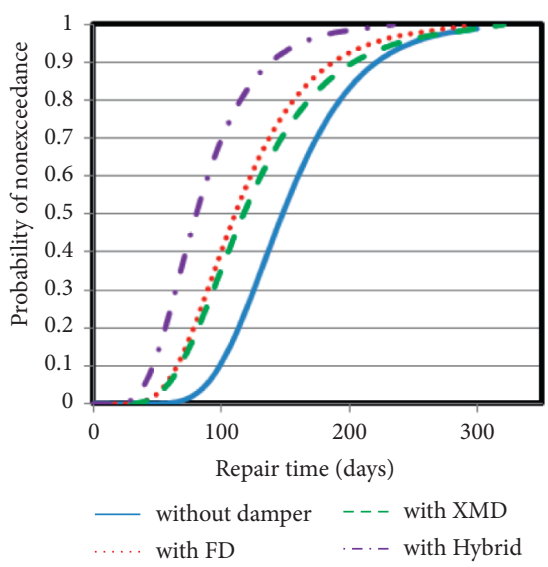

(a)

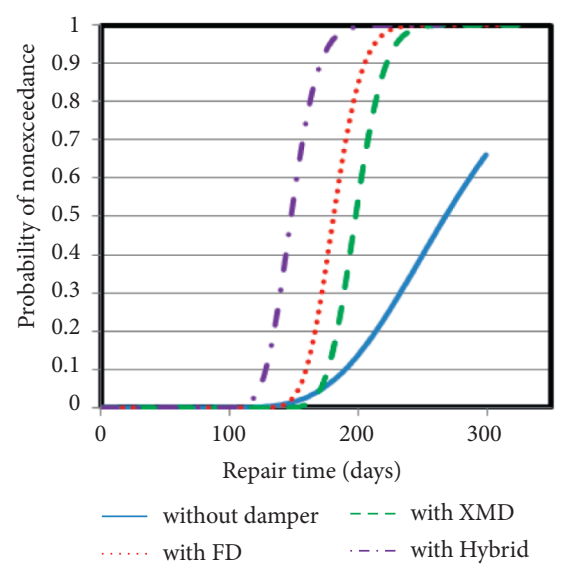

(b)

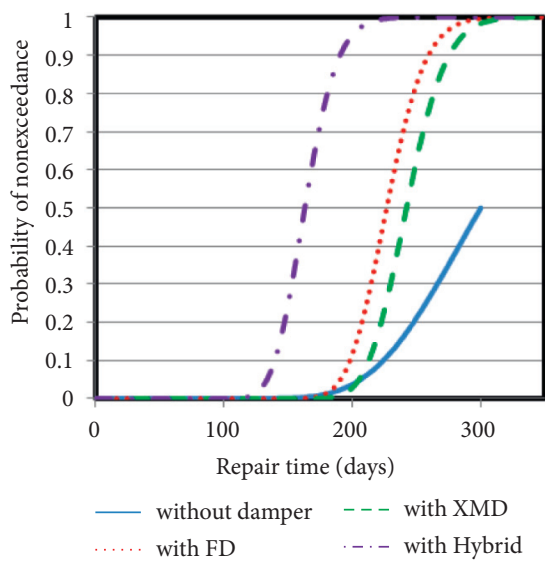

(c)

Figure 18: Cumulative distribution of repair time of a twelve-storey structure under three different intensity earthquakes. (a) Intensity 1. (b) Intensity 2. (c) Intensity 3.

TABLE 8: Mean repair cost of the twelve-storey building without and with dampers.

\begin{tabular}{lcrr}
\hline & \multicolumn{3}{c}{ Mean repair cost in INR (mean repair cost/total replacement cost (\%)) } \\
& Intensity 1 & Intensity 2 & Intensity 3 \\
\hline Structure without damper & $2,60,12,880(33.9 \%)$ & $5,09,40,000(66.5 \%)$ & $6,94,79,928(90.7 \%)$ \\
Structure with the FD & $94,18,320(11.5 \%)$ & $2,03,00,472(24.8 \%)$ & $2,79,83,952(34.2 \%)$ \\
Structure with the XMD & $1,10,45,808(13.3 \%)$ & $2,47,34,088(29.8 \%)$ & $3,49,63,200(42.2 \%)$ \\
Structure with the hybrid damper & $35,80,344(4.2 \%)$ & $1,36,73,952(16.2 \%)$ & $2,13,62,976(25.3 \%)$ \\
\hline
\end{tabular}


TABLE 9: Mean repair time of the twelve-storey building without and with dampers.

\begin{tabular}{lccr}
\hline & \multicolumn{3}{c}{ Mean repair time in days (mean repair time/total replacement time (\%)) } \\
& Intensity 1 & Intensity 2 & Intensity 3 \\
\hline Structure without damper & $147(49 \%)$ & $265(88.3 \%)$ & $299(99.6 \%)$ \\
Structure with the FD & $110(31.4 \%)$ & $181(51.7 \%)$ & $226(64.5 \%)$ \\
Structure with the XMD & $117(33.4 \%)$ & $197(56.2 \%)$ & $243(69.4 \%)$ \\
Structure with the hybrid damper & $80(22.7 \%)$ & $148(42.2 \%)$ & $163(46.5 \%)$ \\
\hline
\end{tabular}

\section{Conclusions}

From this study, the following conclusions are drawn:

When subjected to the nonlinear time history analysis, the maximum interstorey drifts and their averages of both four- and twelve-storey structures under eight earthquake ground motions have surpassed the allowable storey drift before installation of dampers, but after retrofitting structures with dampers, the average of maximum interstorey drifts of both the structures was minimised and is within the target drift. When the four-storey structure is installed with the FD, XMD, and hybrid dampers, the percentage of diminution of average of the maximum interstorey drifts is 67,63 , and 74, respectively, similarly when the twelve-storey structure is installed with the FD, XMD, and hybrid dampers, the percentage of diminution of average of the maximum interstorey drifts is 64,59 , and 71 , respectively. So from this, it can be noticed that the hybrid damper is better than the FD and the XMD in minimising the interstorey drift.

For a four-storey structure under earthquake with PGA equal to $0.07 \mathrm{~g}$ (i.e., earthquake 1), seismic energy dissipated by the FD, XMD, and hybrid dampers is $22 \%, 15 \%$, and $40 \%$, respectively, and under earthquake with PGA equal to $0.4 \mathrm{~g}$ (i.e., earthquake 8 ), seismic energy dissipated by the FD, XMD, and hybrid dampers is $46 \%, 43 \%$, and $75 \%$, respectively. Similarly, for a twelve-storey structure under earthquake with PGA equal to $0.07 \mathrm{~g}$, seismic energy dissipated by the FD, $\mathrm{XMD}$, and hybrid dampers is $19 \%, 15 \%$, and $37 \%$, respectively, and under earthquake with PGA equal to $0.4 \mathrm{~g}$, seismic energy dissipated by the FD, XMD, and hybrid dampers is $45 \%, 43 \%$, and $72 \%$, respectively. From this, it can be noticed that the hybrid damper dissipated more amount of seismic energy than the FD and the XMD under earthquake excitations with both low and high PGA values.

From fragility analysis, it can be observed that the probability of reaching the complete damage state, i.e., collapse can be reduced by the installation of dampers. Both the structures with the hybrid damper have attained lowest probability of collapse when compared to the structures with the FD and the XMD. From fragility analysis, it can be noticed that the hybrid damper is better than the FD and the XMD in minimising the probability of reaching complete damage state, i.e., collapse.
Even though the unit cost of the hybrid damper is higher than the FD and the XMD, the mean repair cost of the structure with the hybrid damper is lower than the structure with the FD and with the XMD under all the three intensity earthquakes. Similarly, even though the time for installation of the hybrid damper is higher than the FD and the XMD, the mean repair time of the structure with the hybrid damper is lower than the structure with the FD and with the XMD under all the three intensity earthquakes. So from the life cycle cost analysis of both the structures, it can be stated that the hybrid damper has performed better than the FD and the XMD of same yield strength.

\section{Data Availability}

The data used to support the findings of this study are included within the article. Further data or information is available from the corresponding author upon request.

\section{Disclosure}

This study was performed as a part of the employment of Kombolcha Institute of Technology, Wollo University, Kombolcha, Amhara, Ethiopia.

\section{Conflicts of Interest}

The authors declare that there are no conflicts of interest regarding the publication of this paper.

\section{Acknowledgments}

The authors thank Aditya College of Engineering, Surampalem, and Saveetha School of Engineering, SIMATS, Chennai, Tamil Nadu, for providing technical support to complete this research work.

\section{References}

[1] R. I. Skinner, J. M. Kelly, and A. J. Heine, "Hysteretic dampers for earthquake-resistant structures," Earthquake Engineering \& Structural Dynamics, vol. 3, no. 3, pp. 287-296, 1974.

[2] A. S. Whittaker, V. V. Bertero, C. L. Thompson, and L. J. Alonso, "Seismic testing of steel plate energy dissipation devices," Earthquake Spectra, vol. 7, no. 4, pp. 563-604, 1991.

[3] C. Xia and R. D. Hanson, "Influence of ADAS element parameters on building seismic response," Journal of Structural Engineering, vol. 118, no. 7, pp. 1903-1918, 1992. 
[4] H.-N. Li and G. Li, "Experimental study of structure with "dual function" metallic dampers," Engineering Structures, vol. 29, no. 8, pp. 1917-1928, 2007.

[5] N. D. K. R. Chukka and M. Krishnamurthy, "Seismic performance assessment of structure with hybrid passive energy dissipation device," Structure, vol. 27, pp. 1246-1259, 2020.

[6] A. S. Pall and C. Marsh, "Response of friction damped braced frames," Journal of the Structural Division, vol. 108, no. 6, pp. 1313-1323, 1982.

[7] G. Anagnostides, A. C. Hargreaves, and T. A. Wyatt, "Development and applications of energy absorption devices based on friction," Journal of Constructional Steel Research, vol. 13, no. 4, pp. 317-336, 1989.

[8] C. E. Grigorian, T. S. Yang, and E. P. Popov, "Slotted bolted connection energy dissipators," Earthquake Spectra, vol. 9, no. 3, pp. 491-504, 1993.

[9] H. S. Monir and K. Zeynali, "A modified friction damper for diagonal bracing of structures," Journal of Constructional Steel Research, vol. 87, pp. 17-30, 2013.

[10] C. A. Martínez and O. Curadelli, “Testing and performance of a new friction damper for seismic vibration control," Journal of Sound and Vibration, vol. 399, pp. 60-74, 2017.

[11] C. N. D. K. Reddy and R. M. Reddy, "Design of a passive energy dissipation system for a building," International Journal for research and development in technology, vol. 7, no. 6, pp. 76-80, 2017.

[12] J. Marko, D. Thambiratnam, and N. Perera, "Influence of damping systems on building structures subject to seismic effects," Engineering Structures, vol. 26, no. 13, pp. 1939-1956, 2004.

[13] Y. E. Ibrahim, J. Marshall, and F. A. Charney, "A visco-plastic device for seismic protection of structures," Journal of Constructional Steel Research, vol. 63, no. 11, pp. 1515-1528, 2007.

[14] T. L. Karavasilis, T. Blakeborough, and M. S. Williams, "Development of nonlinear analytical model and seismic analyses of a steel frame with self-centering devices and viscoelastic dampers," Computers \& Structures, vol. 89, no. 1112, pp. 1232-1240, 2011.

[15] C.-H. Lee, J. Ryu, D.-H. Kim, and Y. K. Ju, "Improving seismic performance of non-ductile reinforced concrete frames through the combined behavior of friction and metallic dampers," Engineering Structures, vol. 172, pp. 304-320, 2018.

[16] Is (Indian Standard), Code of Practice for Design Loads (Other than Earthquakes) for Buildings and Structures, Part 2: Imposed Loads, IS, New Delhi, India, 1987.

[17] Asce/Sei (American Society of Civil Engineers/Structural Engineering Institute of American Society of Civil Engineers), Seismic Rehabilitation of Existing Buildings, ASCE/SEI, Reston, VA, USA, 2007.

[18] Sap, Static and Dynamic Finite Element Analysis of Structures, Computers and Structures, Berkeley, CA, USA, 2000.

[19] N. D. K. R. Chukka and M. Krishnamurthy, "Comparison of $\mathrm{X}$-shaped metallic dampers with fluid viscous dampers and influence of their placement on seismic response of the building," Asian Journal of Civil Engineering, vol. 20, no. 6, pp. 869-882, 2019.

[20] S. Bagheri, M. Barghian, F. Saieri, and A. Farzinfar, "U-shaped metallic-yielding damper in building structures: seismic behavior and comparison with a friction damper," Structure, vol. 3, pp. 163-171, 2015.

[21] J. Kim and H. Shin, "Seismic loss assessment of a structure retrofitted with slit-friction hybrid dampers," Engineering Structures, vol. 130, pp. 336-350, 2017.
[22] M. NourEldin, A. Naeem, and J. Kim, "Life-cycle cost evaluation of steel structures retrofitted with steel slit damper and shape memory alloy-based hybrid damper," Advances in Structural Engineering, vol. 22, no. 1, pp. 3-16, 2018.

[23] Is, Criteria for Earthquake Resistant Design of Structures, Part 1: General Provisions and Buildings, New Delhi, India, IS 1893 part-I, 2016.

[24] Atc, Seismic Evaluation and Retrofit of concrete Buildings, ATC, Redwood City, CA, USA, 1996.

[25] M. C. Constantinou, T. T. Soong, and G. F. Dargush, Passive Energy Dissipation Systems for Structural Design and Retrofit, Multidisciplinary Center For Earthquake Engineering Research, New York, NY, USA, 1998.

[26] A. Pall and R. T. Pall, "Performance based design using pall friction damper- an economical design solution," in Proceedings of the 13th World Conference on Earthquake Engineering, Vancouver, Canada, August 2004.

[27] PEERNGA Database, Pacific Earthquake Engineering Research Center, University of California, Berkeley, CA, USA, 2006, http://www.peer.berkeley.edu/.

[28] S. Mukherjee and V. K. Gupta, "Wavelet-based generation of spectrum-compatible time histories," Soil Dynamics and Earthquake Engineering, vol. 22, no. 1, pp. 799-804, 2002.

[29] J. W. Baker, "Efficient analytical fragility function fitting using dynamic structural analysis," Earthquake Spectra, vol. 31, no. 1, pp. 579-599, 2015.

[30] Fema(Federal Emergency Management Agency), Seismic Performance Assessment of Buildings, Prepared by Applied Technology council for Federal Emergency Management agency, FEMA, Washington, DC, USA, 2018.

[31] International construction market survey, "Turner and townsend," 2019, http://www.infrastructure-intelligence.com/ sites/default/files/article_uploads/Turner\%20Townsend\% 20International\%20Construction\%20Market\%20Survey\% 202019.pdf. 